\title{
Evaluation of the TRPM protein family as potential biomarkers for various types of human cancer using public database analyses
}

\author{
FUCHUANG QIN $^{1}$, LINGDI LAO ${ }^{1}$, MINHUA HUANG $^{2}$, HANG TAN $^{3}$, \\ XUHONG JIN ${ }^{4}$, XILIE MA ${ }^{4}$ and JIANPING ZENG ${ }^{5}$ \\ ${ }^{1}$ Department of Neurosurgery, Shulan (Hangzhou) Hospital, Hangzhou, Zhejiang 310003; \\ ${ }^{2}$ Department of Neurobiology, Zhejiang University School of Medicine, Hangzhou, Zhejiang 310000; \\ ${ }^{3}$ Department of Neurosurgery, Hangzhou Mingzhou Brain Rehabilitation Hospital, Hangzhou, Zhejiang 310012; \\ ${ }^{4}$ Department of Osteology, Hangzhou Red Cross Hospital, Hangzhou, Zhejiang 310004; ${ }^{5}$ Department of Neurosurgery, \\ The First Affiliated Hospital of Medical School of Zhejiang University, Hangzhou, Zhejiang 310003, P.R. China
}

Received June 12, 2019; Accepted October 31, 2019

DOI: $10.3892 /$ etm.2020.8739

\begin{abstract}
The Transient Receptor Potential Melastatin (TRPM) protein family members have been demonstrated to be involved in a variety of different types of human cancer. However, to the best of our knowledge, there has not yet been a systematic study regarding the mRNA expression of the TRPM protein family or its prognostic value in human cancer. The present study investigated TRPM expression and its prognostic value in various human cancer types via the Oncomine database, Kaplan-Meier plotter, and the PrognoScan and Gene Expression Profiling Interactive Analysis databases. It was revealed that the transcriptional levels of TRPM1, TRPM3 and TRPM6 were decreased in the majority of cancer tissues, while TRPM 2 was increased in most cancer types. In addition, the high or low transcriptional levels of the TRPM protein family members were associated with survival outcomes of different types of solid tumors. The present study suggested that certain TRPM protein family members may serve as useful biomarkers for cancer prognosis and anticancer targets for cancer treatment.
\end{abstract}

\section{Introduction}

Cancer is a complex genetic disease in addition to being one of the leading cause of mortality worldwide $(1,2)$. Despite improving diagnostic techniques and therapeutics, cancer

Correspondence to: Dr Xilie Ma, Department of Osteology, Hangzhou Red Cross Hospital, 34 Jianguo Road, Hangzhou, Zhejiang 310004, P.R. China

E-mail: maxilie0571@163.com

Dr Jianping Zeng, Department of Neurosurgery, The First Affiliated Hospital of Medical School of Zhejiang University, 79 Qingchun Road, Hangzhou, Zhejiang 310003, P.R. China

E-mail: jxzjp2013@163.com

Key words: transient receptor potential melastatin, cancer, Oncomine, Gene Expression Profiling Interactive Analysis, prognostic values affects the quality of life of those patients affected, and creates serious social and economic burdens. Therefore, there is an urgent requirement to elucidate the molecular mechanisms underlying cancer development, and to identify novel biomarkers to improve diagnosis, treatment and prognosis. The transient receptor potential (TRP) gene was first cloned in 1989 and categorized into a nonselective cation channel superfamily (3). The human TRP family is divided into six subfamilies: TRPC, TPRV, TRPM, TRPP, TRPML and TRPA. TRPM for 'melastatin' contains 8 members, namely TRPM1, TRPM2, TRPM3, TRPM4, TRPM5, TRPM6, TRPM7 and TRPM8 (4). TRPM 2 has been demonstrated to promote the growth of prostate cancer cells (5). TRPM4 was suggested to enhance cancer cell proliferation via upregulating the $\beta$-catenin signaling pathway (6). TRPM7 has been considered to regulate the migration and invasion of metastatic breast cancer cells (7). Taken together, the TRPM protein family may be attractive targets for anticancer therapies or prognostic biomarkers in certain types of human cancer $(8,9)$. However, to the best of our knowledge, a systematic study on the transcriptional expression and prognostic value of the TRPM protein family members in human tumors has not been conducted yet. In the present study, the mRNA expression patterns of the TRPM protein family between tumor tissues were investigated and compared with normal tissues through the Oncomine database. Furthermore, the present study analyzed prognostic values using The Cancer Genome Atlas (TCGA) database.

\section{Materials and methods}

Oncomine analysis. In the present study, Oncomine (https://www.oncomine.org), an online cancer microarray database, was used to analyze the mRNA expression levels of TRPMs in different types of cancer. The cut-offs were set as fold change $(\mathrm{FC})=2$ and $\mathrm{P}<0.01$, the analysis type was set as cancer vs. normal analysis, and data type as mRNA. The significant differences between cancer and normal tissues, genes, datasets, sample sizes, FC, Student's t-test and P-values were presented. 
Kaplan-Meier plotter analysis. Kaplan-Meier plotter (https://www.kmplot.com) (10), which contains gene expression data and clinical data, was used to evaluate the prognostic value of TRPMs mRNA levels. The present study focused on overall survival (OS) patient information with a 10 -year follow-up. Patient samples were separated into two groups based on their median expression (high and low expression, the median group was included in the high group) in order to estimate the prognostic value of a certain gene. Kaplan-Meier plots were created by analyzing the OS of patients with cancer. $\mathrm{P}<0.05$ was considered to indicate a statistically significant difference. Both log rank P-value and hazard ratio (HR) with 95\% confidence intervals were calculated and summarized. The present study used the best specific probes (JetSet probes) that recognized the TRPM protein family (11).

PrognoScan analysis. The results of the survival analyses were downloaded from PrognScan database (http://dna00.bio. krytech.ac.jp/PrognoScan/index.html/) (12), which is a public microarray database containing clinical annotations of gene expression and the prognostic value of genes, was used to evaluate the prognostic effects of TRPMs in certain types of cancer in the present study. $\mathrm{P}<0.05$ was considered to indicate a statistically significant difference.

Gene Expression Profiling Interactive Analysis (GEPIA). GEPIA (http://gepia.cancer-pku.cn/) (13), an interactive web server for analyzing RNA sequencing expression data, was mined to predict the differential expression levels of TRPM8 in liver and prostate cancer groups compared with the control group. GEPIA was also used to validate gene expression and evaluate the survival analysis of the TRPMs in patients with liver cancer. $\mathrm{P}<0.05$ was considered to indicate a statistically significant difference.

\section{Results}

mRNA expression pattern of the TRPM protein family in different types of human cancer. In order to investigate the transcriptional levels of TRPMs in cancerous and control tissues among the multiple different types of cancer, the present study performed an Oncomine analysis. The database contains a total of 418, 371, 342, 372, 255, 333, 294 and 343 unique analyses for TRPM1, TRPM2, TRPM3, TRPM4, TRPM5, TRPM6, TRPM7 and TRPM8, respectively (Fig. 1). The transcriptional levels of the TRPM family members extracted from the Oncomine database were significantly increased or decreased compared with the normal group in various types of cancer.

The latest data from GLOBOCAN 2018 has reported that there were 18.1 million incident cancer cases and 9.6 million cancer mortalities in 2018 (1). The top 6 types of cancer to be diagnosed in both sexes combined were lung, breast, prostate, colorectal, stomach and liver cancer (1). Melanoma is the fifth most common malignancy in men and the sixth most common in women (14). Therefore, the present study underlined the expression level and prognosis of TRPMs family in these tumors, and certain other common types of solid tumor.

Expression levels and prognostic values of TRPMs in breast cancer. Firstly, the present study investigated the expression levels of the TRPMs family in breast cancer using the Oncomine database. The analysis included 11 datasets in total. According to the TCGA database, TRPM2 was revealed to be upregulated in ductal carcinoma and invasive breast cancer. However, TRPM3 and TRPM6 were downregulated in a variety of different types of breast cancer. Furthermore, TRPM4 was significantly increased only in male breast cancer. No significant differences in TRPM1, TRPM5, TPRM7 and TRPM8 levels were observed between cancerous and control tissues. All the statistically significant results are summarized in Table I.

Breast cancer is now described in terms of intrinsic biological subtypes and is defined into the following four main subtypes: Basal-like (ER-/PR-/HER2-), luminal A (ER ${ }^{+} / \mathrm{HER} 2^{-} /$grade 1 or 2$)$, Basal-like B (ER ${ }^{+} / \mathrm{HER} 2^{-} /$grade 3$)$ and HER2-enriched (any HER2 ${ }^{+}$tumor) (15). The Kaplan-Meier curves presenting the OS of four breast cancer subtypes with a 10-year follow-up are presented in Fig. 2. Poor patient outcome was found to be associated with high expression levels of TRPM2 in the patients with HER2 ${ }^{+}$subtype (Fig. 2D) and low expression of TRPM2 in patients with luminal B subtype (Fig. 2C). High TRPM3 expression was associated with increased OS in luminal B breast carcinoma subtype (Fig. 2G). However, in the patients with the basal (Fig. 2I and M) and HER2+ (Fig. 2L and P) subtypes with a 10-year follow-up, high expression levels of TRPM4 and TRPM6 indicated decreased survival rates.

Expression levels and prognostic values of TRPMs in lung cancer. Using the Oncomine database, the present study analyzed the transcriptional expression of TRPM members in lung cancer. In a group of datasets including Bhattacharjee et al (16) and Garbe et al (17), the transcriptional expression levels of TRPM1 and TRPM2 in small cell lung carcinoma were significantly increased compared with that in the control tissues. According to Bhattacharjee et al (16), TRPM1 also was upregulated in lung carcinoid tumor. According to the dataset from Garber et al (17), it was revealed that TPRM2 was elevated in squamous cell lung carcinoma and large cell lung carcinoma when compared with the control group. According to Okayama et al (18), TRPM6 was decreased in lung adenocarcinoma; however, this was increased in the lung adenocarcinoma samples in the study of Garber et al (17). However, no statistical differences were observed between lung cancer and control tissue groups for TRPM3, TRPM4, TRPM5, TRPM7 and TRPM8 in the present study. The detailed results are presented in Table II.

The present study employed the Kaplan-Meier plotter to identify the role of TRPM protein family in lung adenocarcinoma and squamous cell lung carcinoma, which are the most common types of lung cancer (19). For patients with lung adenocarcinoma, decreased TRPM1 (Fig. 3A) and TRPM2 (Fig. 3C) levels were associated with improved OS. However, decreased TRPM6 (Fig. 3E) were associated with lower OS rates in the patients with lung adenocarcinoma with a 10 -year follow-up. No statistical difference was observed for patients with squamous cell lung carcinoma when regarding OS (Fig. 3B, D and F).

Expression levels and prognostic values of TRPMs in colorectal cancer. As for colon and rectal carcinoma, all 


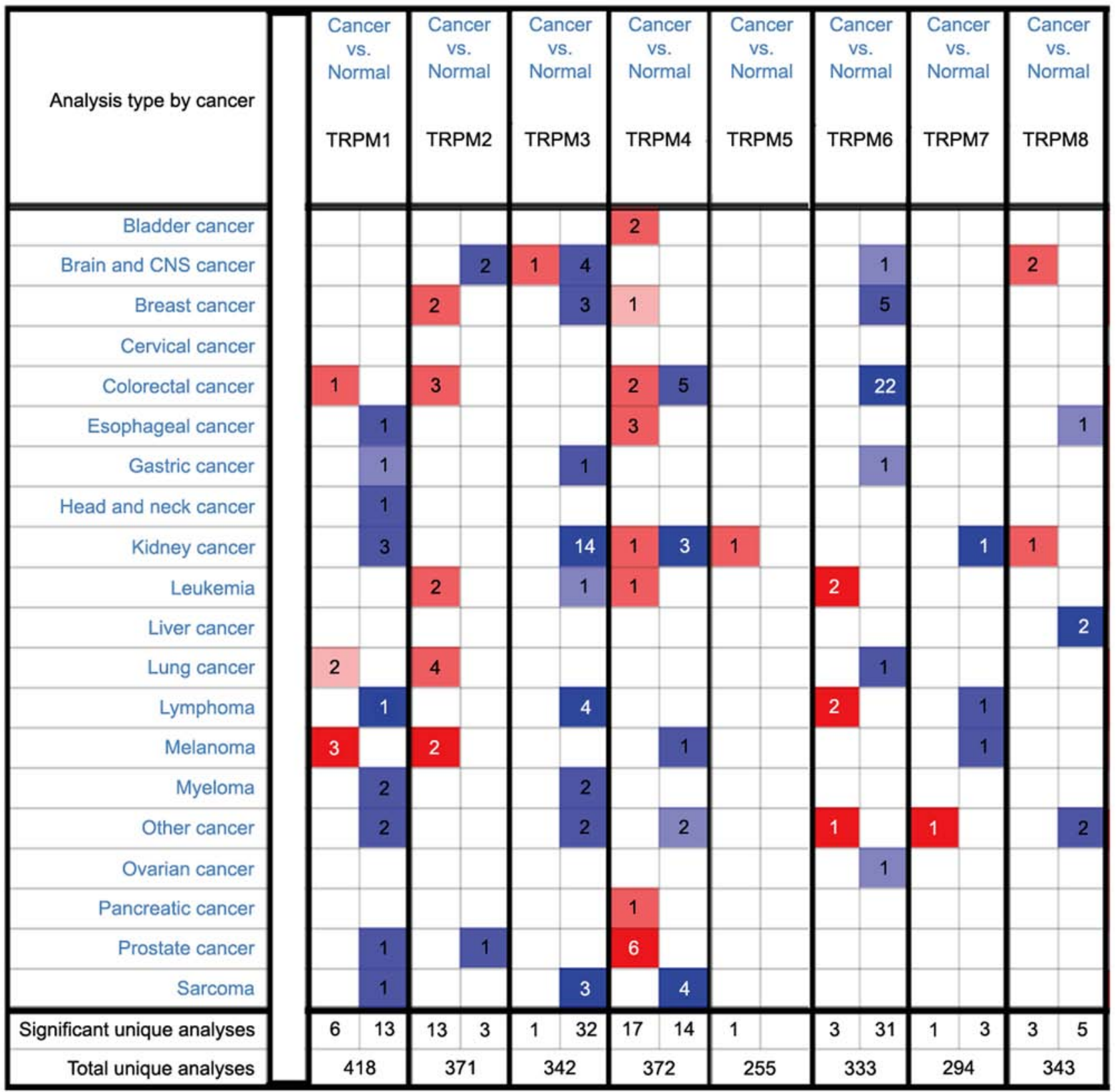

Figure 1. mRNA expression levels of TRPM protein family members in human cancer. The number in the cells represents the number of analyses meeting the thresholds. The cell color is determined by the gene rank. Darker red (upregulated) or blue (downregulated) indicates a more highly significant upregulated or downregulated gene. TRPM, transient receptor potential melastatin.

statistically significant datasets are summarized in Table III. According to TCGA datasets, TRPM1 was increased in rectosigmoid cancer compared with the control tissues. It was revealed that TRPM2 was increased in colon and cecum adenocarcinoma from TCGA datasets. According to Skrzypczak et al (20), TRPM4 was elevated in colon adenoma epithelia, but decreased in colon carcinoma epithelial and colorectal carcinoma compared with colon tissues. In a group of datasets including TCGA and Hong et al (21), TRPM4 was decreased in colon adenocarcinoma, rectal adenocarcinoma and colorectal carcinoma compared with control tissues. This analysis involved 7 datasets in total (20-25), TRPM6 was observed to be upregulated in colon and rectal carcinomas compared with control tissues.
There were no differences in the expression levels of TRPM3, TRPM5, TRPM7 and TRPM8 between colorectal cancer and control tissues.

The associations between TRPM protein family (TRPM1, TRPM2, TRPM4 and TRPM6) and the survival outcomes of patients with colorectal cancer involving OS were determined using the PrognScan database (12). It was revealed that lower expression levels of TRPM1, TRPM2 and TRPM6 were associated with poor prognoses in patients with colorectal cancer. The aberrant regulation of TRPM1, TRPM2 and TRPM6 may contribute to the tumorigenesis and development of colorectal cancer (Fig. 4A, B and D). However, the expression of TRPM4 was not statistically significant in terms of patient prognoses (Fig. 4C). 
Table I. Datasets of TRPM protein family in breast cancer.

\begin{tabular}{lllllrr}
\hline Gene & \multirow{2}{*}{ Dataset } & Normal (n) & \multicolumn{1}{c}{ Tumor (n) } & Fold change & t-test & P-value \\
\hline TRPM2 & \multirow{2}{*}{ TCGA } & Breast (61) & Invasive ductal breast carcinoma (389) & 2.158 & 14.181 & $1.69 \times 10^{-28}$ \\
& & Breast (61) & Invasive breast carcinoma (76) & 2.083 & 7.516 & $3.63 \times 10^{-12}$ \\
TRPM3 & \multirow{2}{*}{ TCGA } & Breast (61) & Invasive breast carcinoma (76) & -2.185 & -12.894 & $1.07 \times 10^{-22}$ \\
& & Breast (61) & Male vreast carcinoma (3) & -2.007 & -7.258 & $8.00 \times 10^{-4}$ \\
& & Breast (61) & Invasive ductal nreast carcinoma (389) & -2.185 & -14.073 & $2.56 \times 10^{-22}$ \\
TRPM4 & TCGA & Breast (61) & Male breast carcinoma (3) & 2.108 & 6.148 & $5.00 \times 10^{-3}$ \\
TRPM6 & TCGA & Breast (61) & Invasive ductal breast carcinoma (389) & -5.432 & -18.443 & $3.50 \times 10^{-37}$ \\
& & Breast (61) & Invasive lobular breast carcinoma (36) & -2.803 & -8.379 & $5.73 \times 10^{-12}$ \\
& & Breast (61) & Mixed lobular and ductal & -3.793 & -6.679 & $7.29 \times 10^{-5}$ \\
& & & breast carcinoma (7) & -5.308 & -9.154 & $2.00 \times 10^{-3}$ \\
& & & Breast (61) & Intraductal cribriform breast & & \\
& & & adenocarcinoma (3) & -3.548 & -8.71
\end{tabular}

TRPMs, Transient Receptor Potential Melastatin; TCGA, The Cancer Genome Atlas.
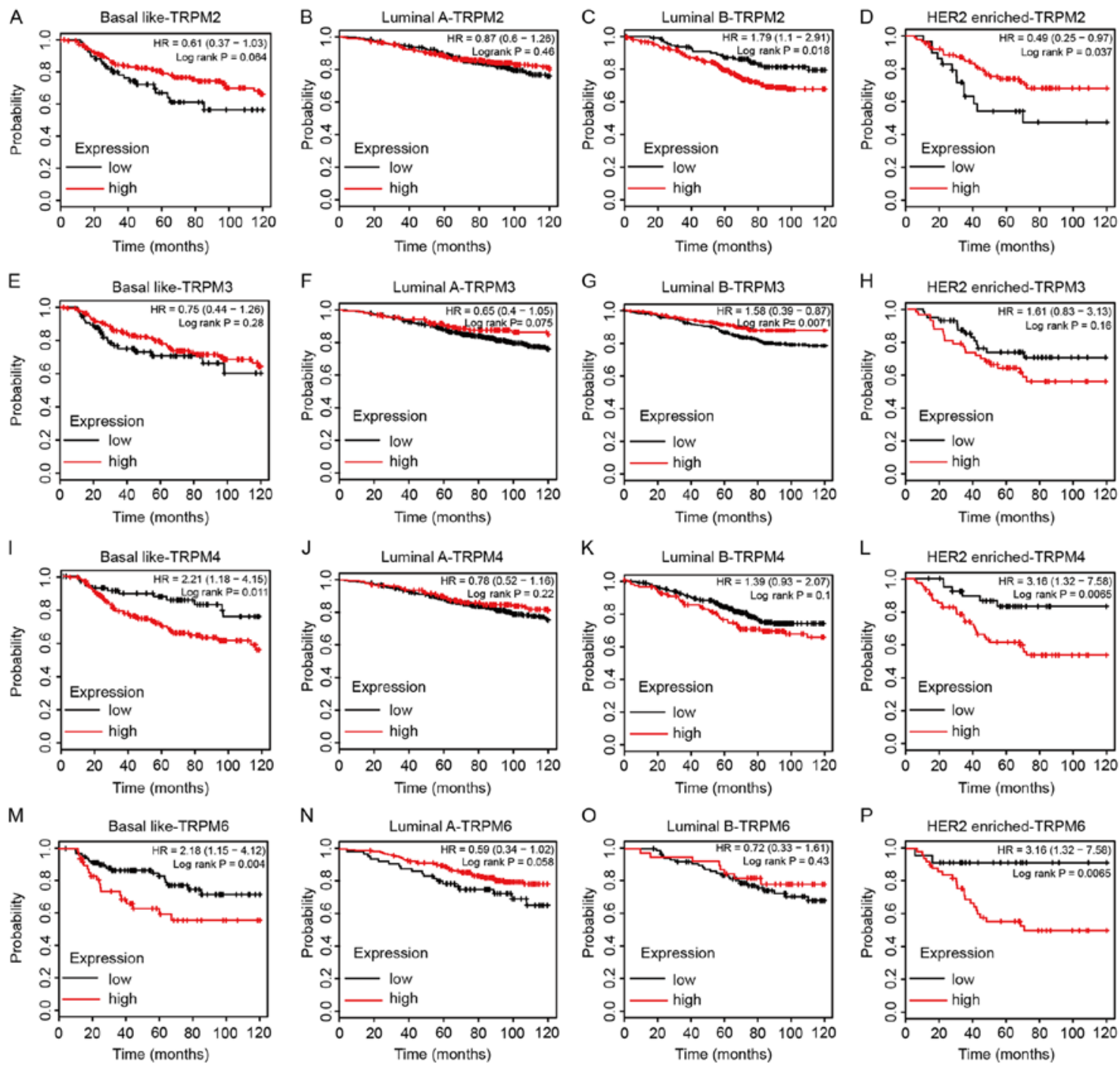

Figure 2. Survival analyses of TRPM protein family in four subtypes of breast cancer: Basallike (ER-/PR/HER2'), luminal A (ER ${ }^{+} / \mathrm{HER}^{-} / \mathrm{grade} 1$ or 2 ), luminal B (ER $/$ HER2/grade 3) and HER2 enriched (any HER2 $2^{+}$tumor). (A-D) Prognosis analysis of TRPM2, (E-H) TRPM3, (I-L) TRPM4 and (M-P) TRPM6. TRPM, transient receptor potential melastatin; ER, estrogen receptor; HER2, human epidermal growth factor receptor 2; HR, hazard ratio. 
Table II. Datasets of TRPM protein family in lung cancer.

\begin{tabular}{|c|c|c|c|c|c|c|}
\hline Gene & Dataset & Normal (n) & Tumor type (n) & Fold change & t-test & P-value \\
\hline \multirow[t]{2}{*}{ TRPM1 } & \multirow[t]{2}{*}{ Bhattacharjee et al (16) } & Lung (17) & Small cell lung carcinoma (6) & 2.24 & 2.664 & 0.007 \\
\hline & & Lung (17) & Lung carcinoid tumor $(20)$ & 2.366 & 2.766 & 0.005 \\
\hline \multirow[t]{8}{*}{ TRPM2 } & \multirow[t]{8}{*}{ Garber et al (17) } & Lung (5) & Large cell lung carcinoma (4) & 4.561 & 5.046 & $5.28 \times 10^{-4}$ \\
\hline & & Fetal lung (1) & & & & \\
\hline & & Lung (5) & Small cell lung carcinoma (4) & 4.068 & 4.404 & 0.001 \\
\hline & & Fetal lung (1) & & & & \\
\hline & & Lung (5) & Lung adenocarcinoma (39) & 3.586 & 5.194 & $5.85 \times 10^{-4}$ \\
\hline & & Fetal lung (1) & & & & \\
\hline & & Lung (5) & Squamous cell lung carcinoma (13) & 3.53 & 3.927 & $7.23 \times 10^{-4}$ \\
\hline & & Fetal lung (1) & & & & \\
\hline TRPM6 & Okayama et al (18) & Lung (20) & Lung adenocarcinoma (226) & -2.363 & -9.369 & $6.51 \times 10^{-12}$ \\
\hline
\end{tabular}

TRPMs, Transient Receptor Potential Melastatin.

A
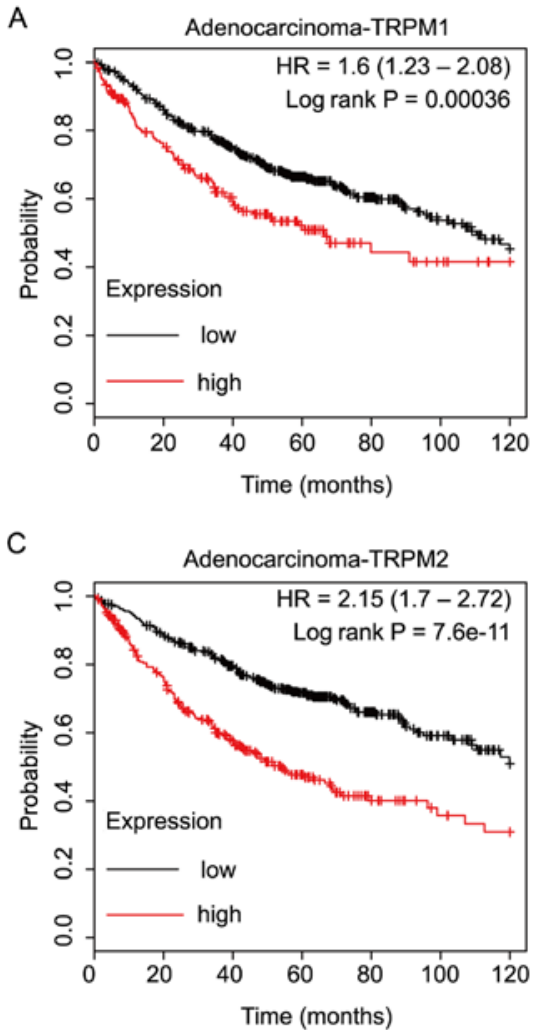

E

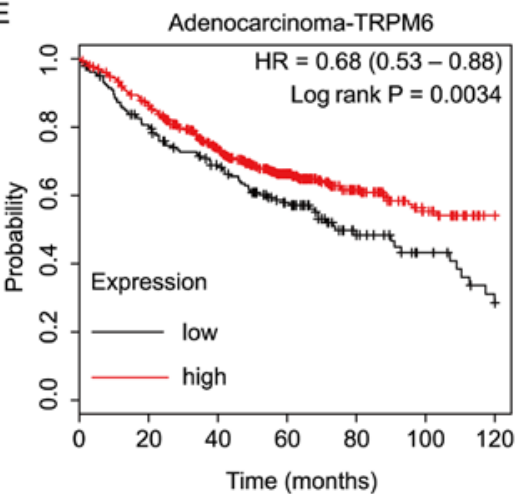

B

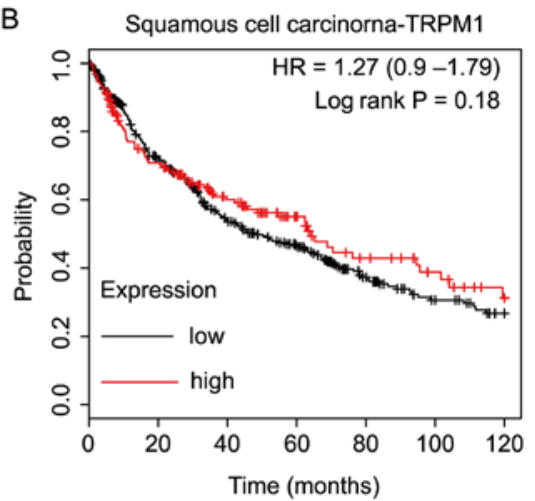

D

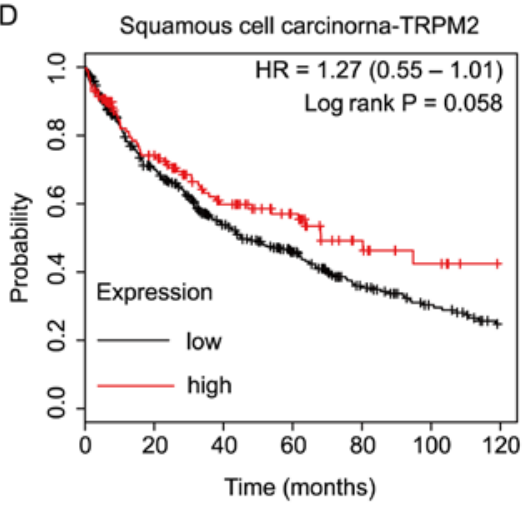

$\mathrm{F}$

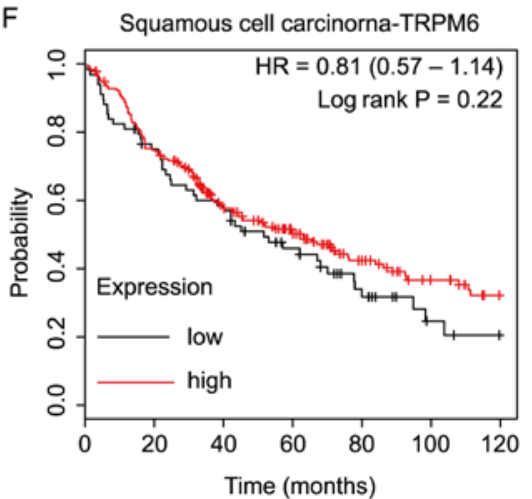

Figure 3. Survival analyses of TRPM protein family in lung adenocarcinoma and squamous cell lung carcinoma. Survival analyses of (A and B) TRPM1, (C and D) TRPM2 and (E and F) TRPM6 were obtained from the Kaplan-Meier plotter database. TRPM, transient receptor potential melastatin; HR, hazard ratio. 
Table III. Datasets of TRPM protein family in colorectal cancer.

\begin{tabular}{|c|c|c|c|c|c|c|}
\hline Gene & Dataset & Normal (n) & Tumor type (n) & Fold change & t-test & P-value \\
\hline TRPM1 & TCGA & $\begin{array}{l}\text { Colon (19) } \\
\text { Rectum (3) }\end{array}$ & $\begin{array}{l}\text { Rectosigmoid } \\
\text { adenocarcinoma ( } 3 \text { ) }\end{array}$ & 3.482 & 9.492 & $9.11 \times 10^{-5}$ \\
\hline \multirow[t]{3}{*}{ TRPM2 } & \multirow[t]{3}{*}{ TCGA } & $\begin{array}{l}\text { Colon (19) } \\
\text { Rectum (3) }\end{array}$ & $\begin{array}{l}\text { Colon mucinous } \\
\text { adenocarcinoma (22) }\end{array}$ & 3.352 & 7.898 & $1.71 \times 10^{-9}$ \\
\hline & & $\begin{array}{l}\text { Colon (19) } \\
\text { Rectum (3) }\end{array}$ & Colon adenocarcinoma (101) & 3.045 & 9.359 & $6.79 \times 10^{-15}$ \\
\hline & & $\begin{array}{l}\text { Colon (19) } \\
\text { Rectum (3) }\end{array}$ & Cecum adenocarcinoma (22) & 3.063 & 7.595 & $3.31 \times 10^{-9}$ \\
\hline TRPM4 & Skrzypczak et al & Colon (10) & Colon adenoma (5) & 2.923 & 10.06 & $1.18 \times 10^{-7}$ \\
\hline \multirow[t]{6}{*}{ TRPM4 } & \multicolumn{2}{|c|}{ Skrzypczak et al (20) Colon (10) } & Colon carcinoma epithelia (5) & -2.232 & -10.598 & $7.31 \times 10^{-7}$ \\
\hline & TCGA & Colon (19) & Colon adenocarcinoma (101) & -2.297 & -10.673 & $1.32 \times 10^{-16}$ \\
\hline & & Rectum (3) & & & & \\
\hline & & $\begin{array}{l}\text { Colon (19) } \\
\text { Rectum (3) }\end{array}$ & Rectal adenocarcinoma (60) & -2.264 & -9.519 & $1.17 \times 10^{-14}$ \\
\hline & Hong et al (21) & Colon (12) & Colorectal carcinoma (70) & -2.67 & -6.172 & $4.22 \times 10^{-8}$ \\
\hline & Skrzypczak et al & $\begin{array}{l}\text { Colorectal } \\
\text { Tissue (24) }\end{array}$ & Colorectal carcinoma (36) & -2.133 & -4.864 & $5.00 \times 10^{-6}$ \\
\hline \multirow[t]{14}{*}{ TRPM6 } & \multicolumn{2}{|c|}{ Skrzypczak et al (20)Colorectal } & Colorectal carcinoma (36) & -15.311 & -12.377 & $7.31 \times 10^{-18}$ \\
\hline & & $\begin{array}{l}\text { Colorectal } \\
\text { Tissue (24) }\end{array}$ & $\begin{array}{l}\text { Colorectal } \\
\text { adenocarcinoma (45) }\end{array}$ & -23.416 & -17.382 & $3.14 \times 10^{-20}$ \\
\hline & \multirow[t]{2}{*}{$\begin{array}{l}\text { Sabates-Bellver } \\
\text { et al (22) }\end{array}$} & $\begin{array}{l}\text { Ascending } \\
\text { Colon (4) } \\
\text { Sigmoid colon (15) } \\
\text { Descending colon (5) } \\
\text { Transverse colon (1) } \\
\text { Rectum (7) }\end{array}$ & \multirow[t]{2}{*}{ Rectal adenoma (7) } & \multirow[t]{2}{*}{-10.094} & -13.134 & $2.76 \times 10^{-9}$ \\
\hline & & $\begin{array}{l}\text { Ascending colon (4) } \\
\text { Sigmoid colon (15) } \\
\text { Descending colon (15) } \\
\text { Transverse colon (1) } \\
\text { Rectum (7) }\end{array}$ & & & -14.421 & $2.09 \times 10^{-17}$ \\
\hline & Hong et al (21) & Colon (12) & Colorectal carcinoma (70) & -17.076 & -18.137 & $2.29 \times 10^{-26}$ \\
\hline & TCGA & $\begin{array}{l}\text { Colon (19) } \\
\text { Rectum (3) }\end{array}$ & Cecum adenocarcinoma (22) & -7.558 & -15.345 & $6.67 \times 10^{-19}$ \\
\hline & TCGA & $\begin{array}{l}\text { Colon (19) } \\
\text { Rectum (3) }\end{array}$ & $\begin{array}{l}\text { Colon mucinous } \\
\text { adenocarcinoma (22) }\end{array}$ & -7.851 & -13.889 & $6.58 \times 10^{-17}$ \\
\hline & TCGA & $\begin{array}{l}\text { Colon (19) } \\
\text { Rectum (3) }\end{array}$ & Colon adenocarcinoma (101) & -15.955 & -17.402 & $4.79 \times 10^{-27}$ \\
\hline & TCGA & $\begin{array}{l}\text { Colon (19) } \\
\text { Rectum (3) }\end{array}$ & Rectal adenocarcinoma (60) & -16.23 & -16.009 & $1.81 \times 10^{-25}$ \\
\hline & TCGA & $\begin{array}{l}\text { Colon (19) } \\
\text { Rectum (3) }\end{array}$ & $\begin{array}{l}\text { Rectosigmoid } \\
\text { adenocarcinoma (3) }\end{array}$ & -6.986 & -13.172 & $5.47 \times 10^{-9}$ \\
\hline & TCGA & $\begin{array}{l}\text { Colon (19) } \\
\text { Rectum (3) }\end{array}$ & $\begin{array}{l}\text { Rectal mucinous } \\
\text { adenocarcinoma (6) }\end{array}$ & -2.486 & -6.936 & $3.47 \times 10^{-6}$ \\
\hline & $\begin{array}{l}\text { Skrzypczak } \\
\text { et al }(23)\end{array}$ & Colon (10) & Colon adenoma (5) & -14.37 & -18.47 & $8.42 \times 10^{-11}$ \\
\hline & $\begin{array}{l}\text { Skrzypczak } \\
\text { et al }(23)\end{array}$ & Colon (10) & Colon adenoma epithelia (5) & -23.56 & -17.083 & $6.31 \times 10^{-10}$ \\
\hline & $\begin{array}{l}\text { Skrzypczak } \\
\text { et al (23) }\end{array}$ & Colon (10) & Colon carcinoma (5) & -41.197 & -25.401 & $1.64 \times 10^{-10}$ \\
\hline
\end{tabular}


Table III. Continued.

\begin{tabular}{|c|c|c|c|c|c|c|}
\hline Gene & Dataset & Normal (n) & Tumor type (n) & Fold change & t-test & P-value \\
\hline & $\begin{array}{l}\text { Skrzypczak } \\
\text { et al }(23)\end{array}$ & Colon (10) & Colon carcinoma epithelia (5) & -15.226 & -15.723 & $7.73 \times 10^{-10}$ \\
\hline & Gaedcke et al (24) & Rectum (65) & Rectal adenocarcinoma (65) & -2.345 & -17.187 & $2.83 \times 10^{-10}$ \\
\hline & Kaiser et al (25) & Colon (5) & $\begin{array}{l}\text { Rectal mucinous } \\
\text { adenocarcinoma (4) }\end{array}$ & -3.254 & -10.995 & $6.20 \times 10^{-5}$ \\
\hline & Kaiser et al (25) & Colon (5) & Rectal adenocarcinoma (8) & -2.893 & -8.959 & $2.39 \times 10^{-5}$ \\
\hline & Kaiser et al (25) & Colon (5) & $\begin{array}{l}\text { Rectosigmoid } \\
\text { adenocarcinoma (10) }\end{array}$ & -2.579 & -6.526 & $1.92 \times 10^{-5}$ \\
\hline & Kaiser et al (25) & Colon (5) & $\begin{array}{l}\text { Colon mucinous } \\
\text { adenocarcinoma (13) }\end{array}$ & -13.448 & -9.454 & $1.72 \times 10^{-5}$ \\
\hline & Kaiser et al (25) & Colon (5) & Cecum adenocarcinoma (17) & -2.538 & -7.776 & $3.94 \times 10^{-5}$ \\
\hline & Kaiser et al (25) & Colon (5) & Colon adenocarcinoma (41) & -2.785 & -9.252 & $6.54 \times 10^{-5}$ \\
\hline
\end{tabular}

TRPMs, Transient Receptor Potential Melastatin; TCGA, The Cancer Genome Atlas.

A

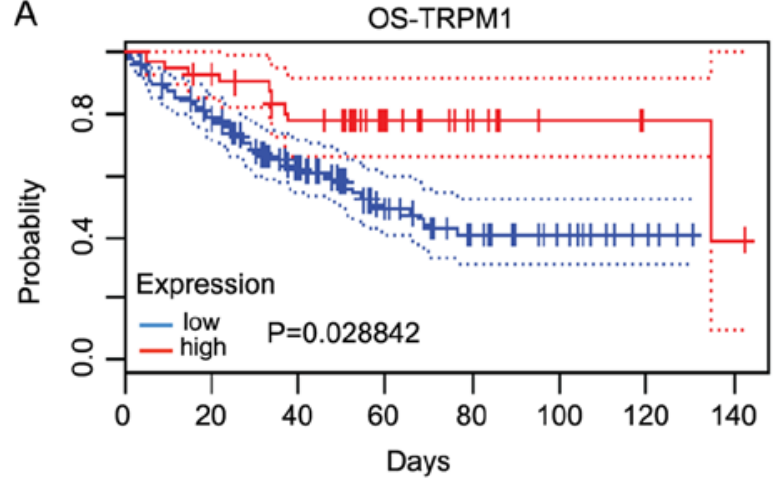

C

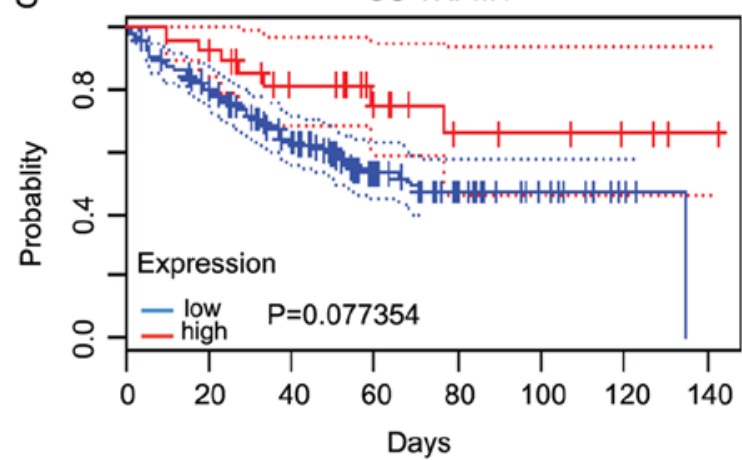

B

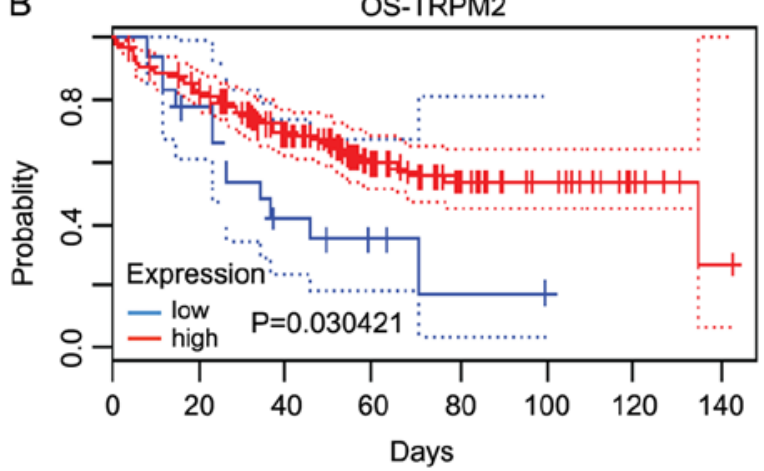

$\mathrm{D}$

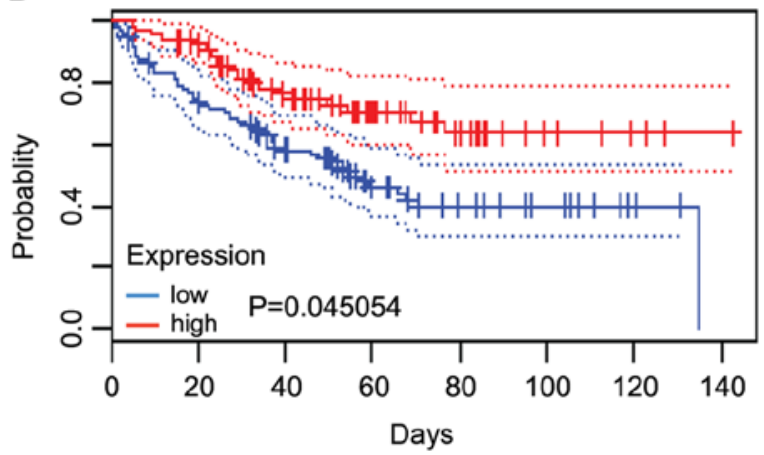

Figure 4. Survival analyses of TRPM protein family in colorectal cancer. Survival analyses of (A) TRPM1, (B) TRPM2, (C) TRPM4 and (D) TRPM6 were obtained from the Kaplan-Meier Plotter database. TRPM, transient receptor potential melastatin; OS, overall survival.

Expression levels and prognostic values of TRPMs in gastric cancer. In the dataset from D'Errico et al (26), TRPM1 and TRPM6 were decreased in gastric mixed adenocarcinoma compared with in gastric mucosa. According to Wang et al (27), it was revealed that TRPM3 levels were decreased in gastric cancer compared with gastric mucosa and gastric tissue. However, there was no difference observed in the expression levels between gastric cancer and control tissue groups in the other members of the
TRPM protein family. The detailed results are presented in Table IV.

The present study then assessed the prognostic effects of TRPM1, TRPM3 and TRPM6 in gastric cancer. The prognostic effects of these genes are presented in Fig. 5. For intestinal-type patients, high mRNA expression levels of TRPM1, TRPM3 and TPRM6 were significantly associated with improved OS [TRPM1: Hazard ratio $(\mathrm{HR})=1.4$ (1.02-1.92); $\mathrm{P}=0.035$; TRPM3: HR, 1.68 (1.23-2.31); $\mathrm{P}=0.0011$; TRPM6: $\mathrm{HR}=1.64$ 
Table IV. Datasets of TRPM protein family in gastric cancer.

\begin{tabular}{|c|c|c|c|c|c|c|}
\hline Gene & Dataset & Normal (n) & Tumor type (n) & Fold change & t-test & P-value \\
\hline TPRM1 & \multicolumn{2}{|c|}{ D' Errico et al (26) Gastric mucosa (31) } & $\begin{array}{l}\text { Gastric mixed } \\
\text { adenocarcinoma (4) }\end{array}$ & -3.576 & -3.638 & 0.008 \\
\hline TPRM3 & Wang et al (27) & $\begin{array}{l}\text { Gastric mucosa (12) } \\
\text { Gastric tissue (3) }\end{array}$ & Gastric cancer (12) & -3.251 & -3.398 & 0.001 \\
\hline TRPM6 & D' Errico et al $(2$ & Gastric mucosa (31) & $\begin{array}{l}\text { Gastric mixed } \\
\text { adenocarcinoma (4) }\end{array}$ & -2.025 & -4.013 & 0.004 \\
\hline
\end{tabular}

TRPMs, Transient Receptor Potential Melastatin.

A

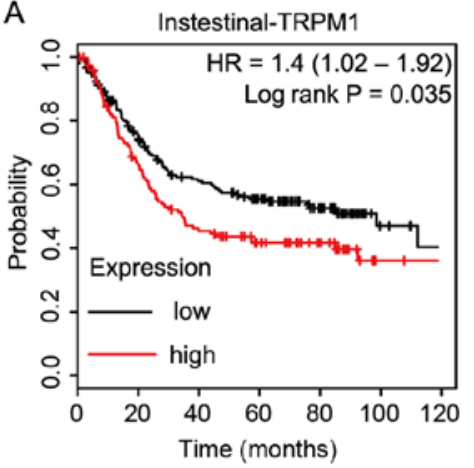

D

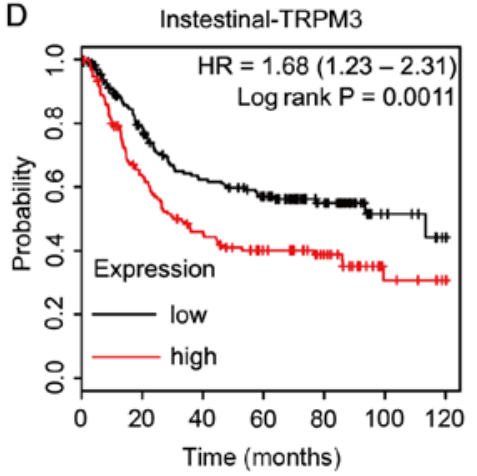

G

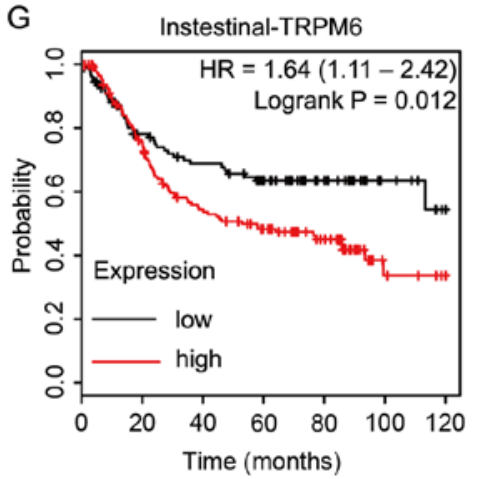

B

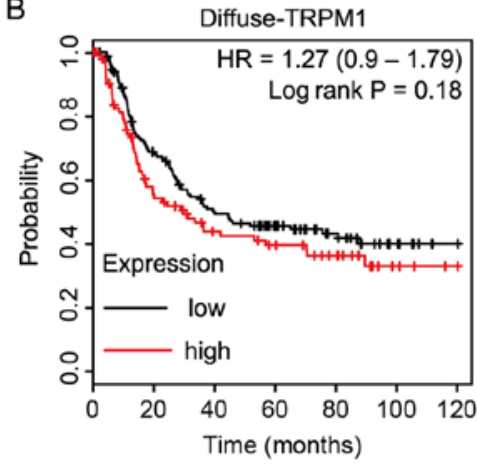

E

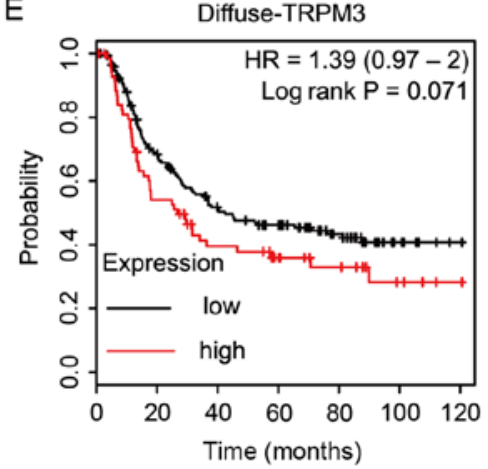

$\mathrm{H}$

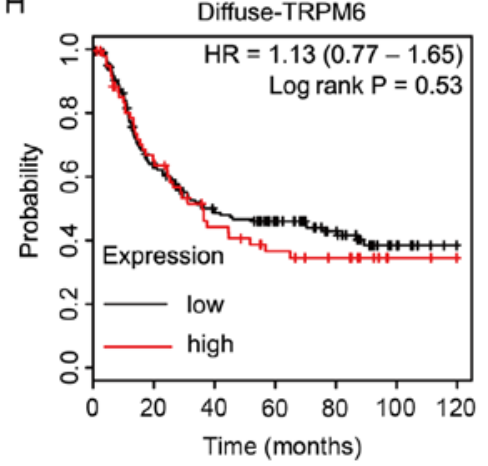

C

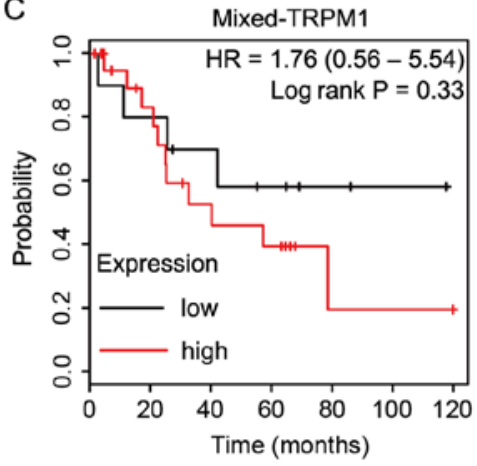

$\mathrm{F}$

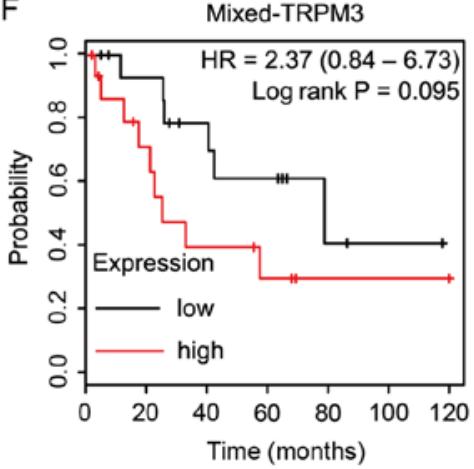

I

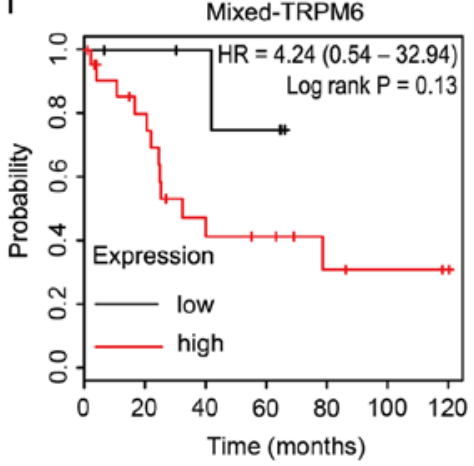

Figure 5. Survival analyses of the TRPM protein family in gastric cancer. Survival analyses of (A-C) TRPM1 (D-F), TRPM3 and (G-I) TRPM6 were obtained from the Kaplan-Meier Plotter database. TRPM, transient receptor potential melastatin; HR, hazard ratio.

(1.11-2.42); $\mathrm{P}=0.012]$. However, it was revealed that the mRNA expression levels of TRPM1, TRPM3 and TRPM6 were not associated with longer OS in patients with gastric mixed types and diffuse types of cancer.
Expression levels and prognostic values of TRPMs liver cancer. By analyzing the Oncomine database, only TRPM8 was differentially expressed; its mRNA expression level was significantly increased compared with that in the control liver 
A

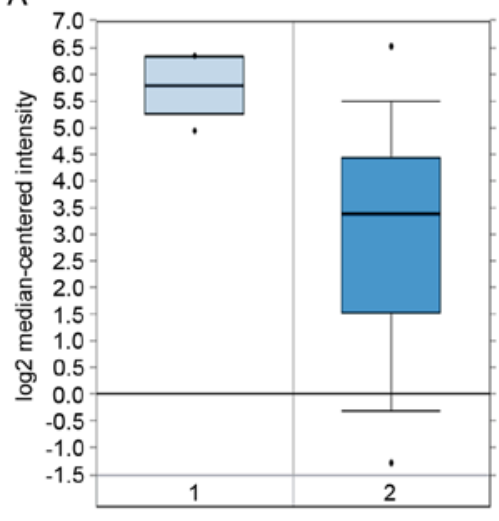

B

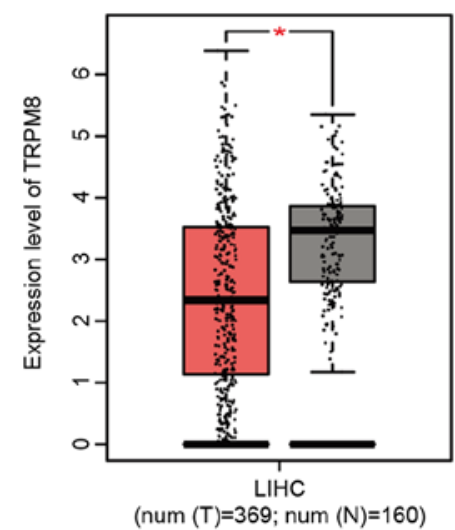

C

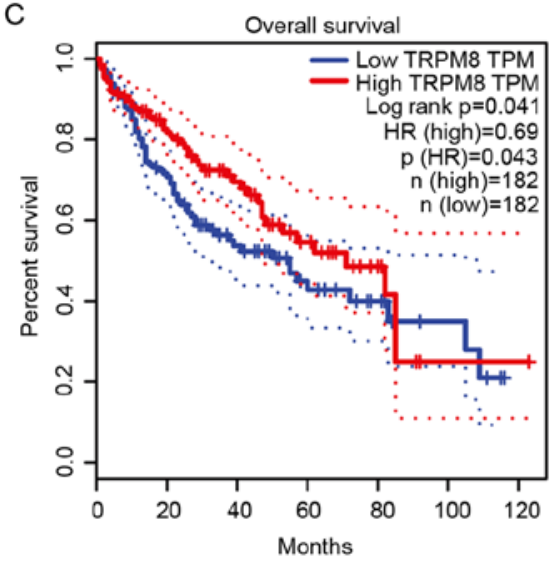

Figure 6. Validation of TRPM8 in liver cancer. (A) Data obtained from the Oncomine database indicated that TRPM8 was significantly downregulated in liver cancer tissues. (B) The GEPIA database also revealed a decreased expression level of TRPM8 in liver cancer tissues compared with control colon tissues. ${ }^{*} \mathrm{P}<0.05$. (C) Kaplan-Meier survival curves obtained from the GEPIA database indicated that patients with liver cancer exhibiting increased expression levels of TRPM8 exhibited improved overall survival time. TRPM, transient receptor potential melastatin; GEPIA, Gene Expression Profiling Interactive Analysis; HR, hazard ratio; LIHC, liver hepatocellular carcinoma.

tissues $(\mathrm{FC}=-6.512 ; \mathrm{P}=7.31 \mathrm{E}-09$; Fig. 6A). In addition, the present study further determined that the TRPM8 levels were significantly elevated in liver cancer tissues by analyzing the GEPIA database $(\mathrm{P}<0.05$; Fig. 6B). In addition, the present study mapped the survival curves of patients with high (red) and low (black) expression of liver cancer from the GEPIA database, demonstrating that the OS time of patients with high TRPM8 gene expression was significantly shorter $(\mathrm{HR}=0.69$; $\mathrm{P}=0.041$; Fig. 6C).

Expression levels and prognostic values of TRPMs in prostate cancer. In the Oncomine database, 7 datasets possessed significant differences between prostate cancer and control tissue in total. According to Tomlins et al (28), TRPM1 and TRPM2 levels were decreased in prostate cancer (TRPM1: $\mathrm{FC}=-2.195 ; \mathrm{t}=-3.77 ; \mathrm{P}=3.12 \times 10^{-4} ; \mathrm{TRPM} 2: \mathrm{FC}=-2.455$; $\left.\mathrm{t}=-4.001 ; \mathrm{P}=1.75 \times 10^{-4}\right)$. However, the opposite conclusion was drawn from a series of databases that demonstrated that TRPM4 and TRPM8 were increased in prostate cancer when compared with the normal prostate (29-34). The detailed results are presented in Table $\mathrm{V}$.

Subsequently, the present study evaluated the prognostic effect of the TRPM protein family members (TRPM1, TRPM2, TRPM4 and TRPM8) on the prognosis of prostate cancer through the PrognoScan database. Only TRPM8 expression exhibited a statistically significant association with the prognosis of the patient $[\mathrm{P}=0.006968 ; \mathrm{HR}=0.87$ (0.78-0.96); Fig. 7].

Expression levels and prognostic values of TRPMs in melanoma. A total of 3 datasets revealed significant differences between melanoma and control tissues in the Oncomine database. In the studies by Talantov et al (35) and Haqq et al (36), it was revealed that the level of TRPM1 expression in control skin tissues was low, while it increased markedly in melanoma samples. According to Haqq et al (36), TRPM2 was also demonstrated to be upregulated in melanoma tissues when compared with control skin tissues. However, in the study conducted by Riker et al (37), the expression levels of TRPM4 and TRPM7 were markedly elevated in cutaneous melanoma samples when compared with control tissues. The results are presented in Table VI.

To further assess the role of TRPM protein family in cancer progression of patients with melanoma, the present study used the PrognoScan database to calculate prognostic values based on cox $\mathrm{P}<0.05$ (12). As presented in Fig. 8, TRPM1 and TRPM4 were significantly associated with OS.

Expression levels and prognostic values of TRPMs in other types of cancer. The present study also analyzed the transcriptional level of TRPMs in certain other types of solid tumor. It was suggested that the most marked differences were observed in kidney cancer, esophageal cancer, brain and central nervous system (CNS) cancer, and head and neck cancer (Fig. 1). All the detailed analyses of the aforementioned cancer types are summarized in Table VII. For clear cell renal cell carcinoma, which is the most common type of kidney cancer, all genes were downregulated (38-42). TRPM4, TPRM5 and TRPM8 in the study by Yusenko et al (43) were increased in renal oncocytoma samples when compared with the control group. However, there were no statistically significant differences observed in TRPM2 and TRPM6 levels between kidney cancer and control tissues. TRPM4 expression was upregulated in esophageal cancer, while TRPM1 and TRPM8 expression levels were decreased (44-46). In the cases of brain and CNS cancer, TRPM2, TRPM3 and TRPM6 were expressed at low levels in different types of brain and CNS cancer (47-51). However, TRPM8 was elevated in glioblastoma when compared with control brain tissues in the data by Murat et al (51) and Lee et al (49). Notably, only TRPM1 was expressed at an increased level in head and neck squamous cell carcinoma when compared with buccal mucosa $(\mathrm{FC}=-5.324 ; \mathrm{t}$, -8.031; $\mathrm{P}=1.52 \mathrm{E}-10)$ according to the study by Ginos et al (52).

Subsequently, the present study further analyzed the association between the TRPMs and the survival rate of patients in all the aforementioned types of cancer using the PrognoScan database (12). In conclusion, the effect of the TRPM protein family on the prognosis of renal cancer was not significant. In particular, the high expression of TRPM8 was 
Table V. Datasets of TRPM protein family in prostate cancer.

\begin{tabular}{|c|c|c|c|c|c|c|}
\hline Gene & Dataset & Normal (n) & Tumor type (n) & $\begin{array}{c}\text { Fold } \\
\text { change }\end{array}$ & t-test & P-value \\
\hline TRPM1 & Tomlins et al (28) & Prostate gland (23) & Prostatic intraepithelial neoplasia (13) & -2.195 & -3.77 & $3.12 \times 10^{-4}$ \\
\hline TRPM2 & Tomlins et al (28) & Prostate gland (21) & Prostatic intraepithelial neoplasia (13) & -2.455 & -4.001 & $1.75 \times 10^{-4}$ \\
\hline \multirow[t]{6}{*}{ TRPM4 } & Varambally et al (29) & Prostate gland (6) & Prostate carcinoma $(7)$ & 3.622 & 8.767 & $3.94 \times 10^{-6}$ \\
\hline & Liu et al (30) & Prostate gland (13) & Prostate carcinoma (44) & 2.753 & 5.931 & $2.57 \times 10^{-6}$ \\
\hline & Vanaja et al (31) & Prostate gland (8) & Prostate adenocarcinoma (27) & 3.937 & 6.464 & $4.24 \times 10^{-7}$ \\
\hline & Grasso et al (32) & Prostate gland (28) & Prostate carcinoma $(59)$ & 3.059 & 8.109 & $7.08 \times 10^{-11}$ \\
\hline & Arredouani et al (33) & Prostate gland (8) & Prostate carcinoma (13) & 2.761 & 4.796 & $1.13 \times 10^{-11}$ \\
\hline & Wallace et al (34) & Prostate gland (20) & Prostate adenocarcinoma (69) & 4.542 & 4.226 & $1.59 \times 10^{-4}$ \\
\hline TRPM8 & Vanaja et al (31) & Prostate gland (8) & Prostate adenocarcinoma (27) & 2.883 & 3.082 & 0.005 \\
\hline
\end{tabular}

TRPMs, Transient Receptor Potential Melastatin; TCGA, The Cancer Genome Atlas.
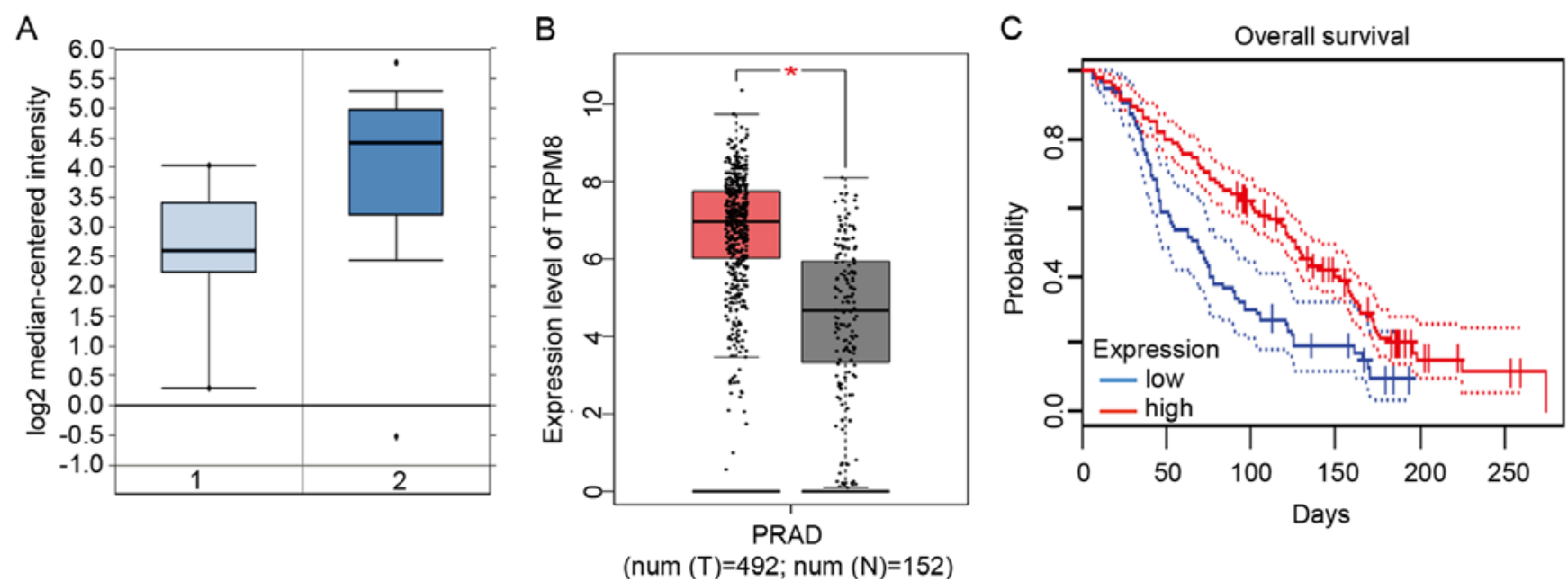

Figure 7. Validation of TRPM8 in prostate cancer. (A) Data obtained from the Oncomine database indicated that TRPM8 was significantly upregulated in prostate cancer tissues. (B) The GEPIA database also revealed a decreased expression level of TRPM8 in prostate cancer tissues compared with normal colon tissues. "P $<0.05$. (C) Kaplan-Meier survival curves obtained from the PrognoScan databases indicated that patients with prostate cancer exhibiting increased expression levels of TRPM8 had a poorer overall survival time. TRPM, transient receptor potential melastatin; GEPIA, Gene Expression Profiling Interactive Analysis; PRAD, prostate adenocarcinoma.

associated with poor OS in patients with esophageal cancer $[\mathrm{P}=0.001214 ; \mathrm{HR}=225.46(8.47-6004.05)]$. As for brain cancer, increasing TRPM6 levels were associated with poor prognosis $[\mathrm{P}=0.010649 ; \mathrm{HR}=3.70$ (1.36-10.09)]. However, there may be no association between this protein family with the survival outcomes of patients with head and neck cancer.

\section{Discussion}

Despite increasing advances in early diagnosis and treatment options, cancer remains a significant cause of morbidity and mortality worldwide $(1,53,54)$. Tumor formation and metastasis is a complex process, and is the result of various gene dysregulation events and cellular processes, including tumorigenesis, basement membrane degradation, matrix permeability, cell adhesion and angiogenesis. $\mathrm{Ca}^{2+}$ signaling pathways are necessary for regulation of the cell cycle, cell proliferation and apoptosis, and are involved in the process of tumorigenesis (55). TRPM, one superfamily of the TRP cation channel, contributes to the regulation of intracellular $\mathrm{Ca}^{2+}$ concentration $(56,57)$. The TRPM protein family consists of 8 structural and functional channels that are widely expressed in a number of different types of tissue and have diverse physiological functions (8). The TRPM protein family may serve as triggers for enhanced proliferation and aberrant differentiation, which leads to the pathogenic proliferative and invasive characteristics of cancer (58). Differences in expression of the TRPM channels may provide a new basis for tumor diagnosis, and may be a novel target for cancer therapy. The present study used the Oncomine database to systematically analyze the mRNA expression levels of the TRPM protein family in different types of tumor, and assessed the prognostic values using the Kaplan-Meier plotter, and PrognoScan and GEPIA databases.

Breast cancer remains the most common type of malignant tumor and the leading cause of cancer-associated mortality among women worldwide $(1,59)$. Due to its high heterogeneity, it is necessary to constantly investigate new biomarkers 
Table VI. Datasets of TRPM protein family in melanoma.

\begin{tabular}{lllllll}
\hline \multirow{2}{*}{ Gene } & Dataset & Normal (n) & \multicolumn{1}{c}{ Tumor type (n) } & $\begin{array}{c}\text { Fold } \\
\text { change }\end{array}$ & t-test & P-value \\
\hline TRPM1 & Talantov et al (35) & Skin (7) & Benign melanocytic skin nevus (18) & 34.333 & 7.586 & $4.13 \times 10^{-7}$ \\
& Talantov et al (35) & Skin (7) & Cutaneous melanoma (45) & 19.17 & 8.278 & $2.83 \times 10^{-5}$ \\
& Haqq et al (36) & Skin (3) & Non-neoplastic nevus (9) & 2.634 & 6.291 & $5.33 \times 10^{-5}$ \\
TRPM2 & Haqq et al (36) & Skin (3) & Melanoma (6) & 3.106 & 10.783 & $6.70 \times 10^{-6}$ \\
& Haqq et al (36) & Skin (3) & Non-neoplastic nevus (9) & 2.316 & 7.136 & $1.58 \times 10^{-5}$ \\
TRPM4 & Riker et al (37) & Skin (4) & Cutaneous melanoma (14) & -7.112 & -5.004 & $6.51 \times 10^{-5}$ \\
TRPM7 & Riker et al (37) & Skin (4) & Cutaneous melanoma (14) & -2.601 & -3.968 & $5.59 \times 10^{-4}$ \\
\hline
\end{tabular}

TRPMs, Transient Receptor Potential Melastatin.

A

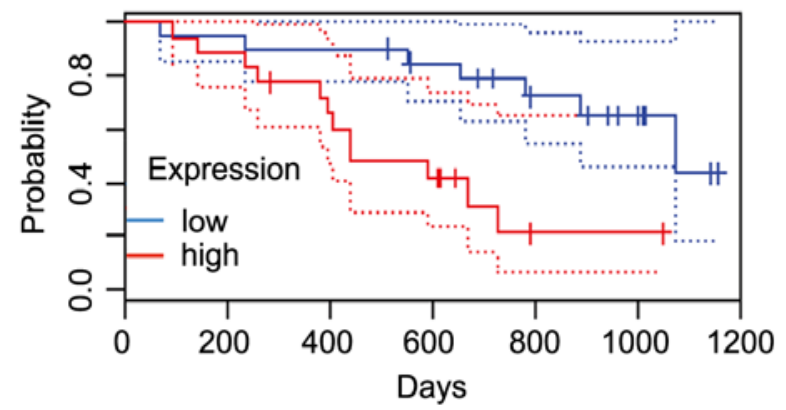

C

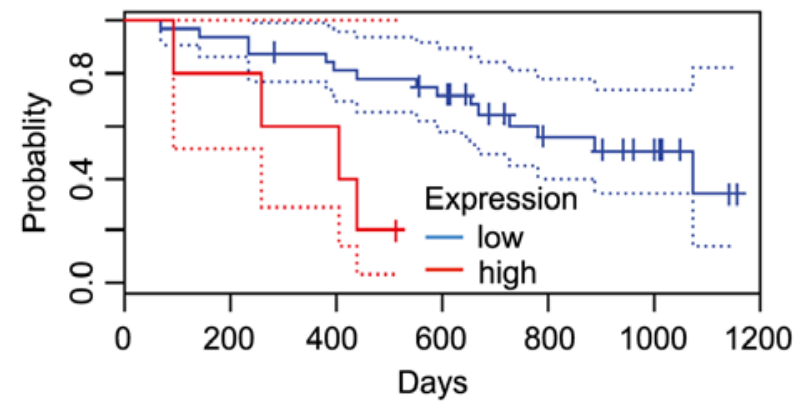

B

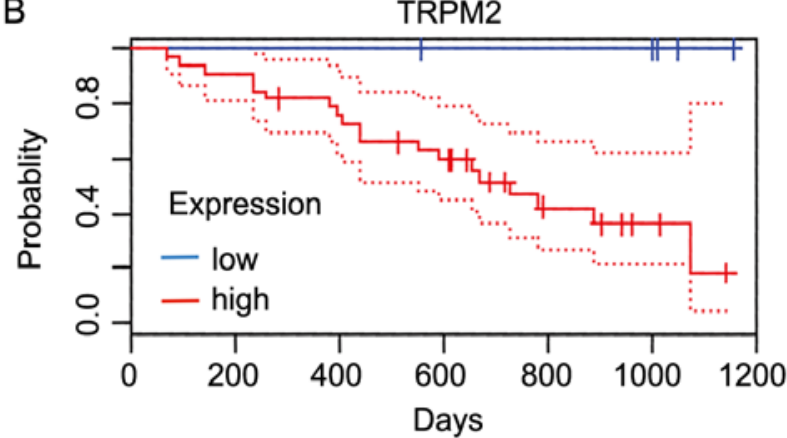

D

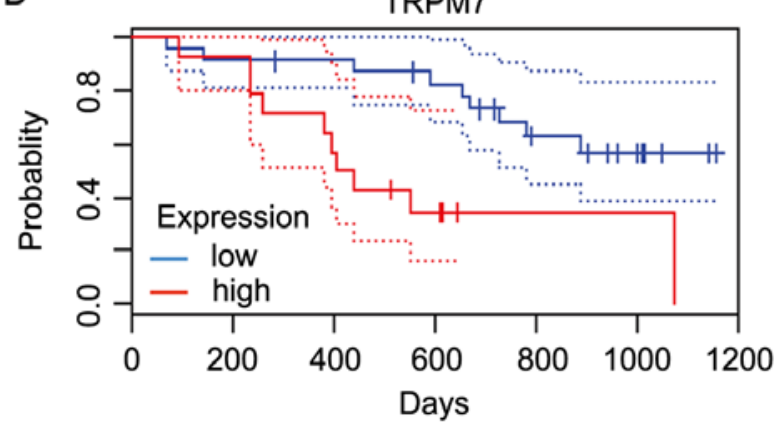

Figure 8. Survival analyses of TRPM protein family in melanoma. Survival analyses of (A) TRPM1, (B) TRPM2, (C) TRPM4 and (D) TRPM7 were obtained from the Kaplan-Meier Plotter database. TRPM, transient receptor potential melastatin.

in order to distinguish different subtypes and predict their clinical behavior and therapeutic response (60-62). The expression of TRPM2 and TRPM4 were upregulated in ductal carcinoma and invasive breast cancer when compared with control breast tissue. By contrast, TCGA database demonstrated that TRPM3 and TRPM6 were downregulated in invasive breast tumors. The results from the present study suggested that TRPM2, TRPM3, TRPM4 and TRPM6 may be used as molecular biomarkers to identify breast cancer invasion (63). The Kaplan-Meier analysis demonstrated that decreased TRPM2 may be used to predict prognosis in patients with Luminal B breast cancer and HER2 $2^{+}$breast cancer subtypes. High expression of TRPM4 and TRPM6 indicated lower survival rates in patients with basal and HER $2^{+}$subtypes. In addition, according to the analysis of the present study, TPRM3 may be used as a biomarker for the Luminal B breast cancer subtype. The results suggested that certain members of the TRPM family may be potential biomarkers and targets for new breast cancer therapies. Associations between TRPM proteins and breast cancer continue to be identified as a result of rapid advances in molecular biology and genetics research (9). In addition, TRPM6 somatic mutations have also been observed in an independent cohort of breast cancer samples (64).

Lung cancer has the highest rates of incidence and mortality in China (65) and around the world (66). The present study systemically analyzed the expression and prognostic value of TRPMs in lung cancer. The results indicated that the decreased expression levels of TRPM1 and TRPM2, and increased expression levels of TRPM6 in lung adenocarcinoma may serve an important role in lung cancer tumorigenesis. The present study revealed that transcriptional TRPM2 is a novel 
Table VII. Datasets of TRPM family in other cancers.

\begin{tabular}{|c|c|c|c|c|c|c|c|}
\hline $\begin{array}{l}\text { Cancer } \\
\text { type }\end{array}$ & Gene & Dataset & Normal (n) & Tumor type (n) & $\begin{array}{l}\text { Fold } \\
\text { change }\end{array}$ & t-test & P-value \\
\hline \multirow[t]{24}{*}{ Kidney } & \multirow[t]{3}{*}{ TRPM1 } & Cutcliffe et al (38) & Fetal kidney (3) & Renal wilms tumor (18) & -2.541 & -3.605 & $9.45 \times 10^{-4}$ \\
\hline & & Jones et al (39) & Kidney (23) & $\begin{array}{l}\text { Clear cell renal cell } \\
\text { carcinoma }(23)\end{array}$ & -4.321 & -16.61 & $3.60 \times 10^{-16}$ \\
\hline & & Jones et al (39) & Kidney (23) & $\begin{array}{l}\text { Renal pelvis urothelial } \\
\text { carcinoma (8) }\end{array}$ & -3.927 & -15.642 & $4.53 \times 10^{-8}$ \\
\hline & \multirow[t]{14}{*}{ TRPM3 } & Cutcliffe et al (38) & Fetal kidney (3) & Renal wilms tumor (18) & -2.484 & -9.971 & $3.28 \times 10^{-9}$ \\
\hline & & Cutcliffe et al (38) & Fetal kidney (3) & $\begin{array}{l}\text { Clear cell sarcoma of } \\
\text { the kidney (14) }\end{array}$ & -2.3 & -8.486 & $2.07 \times 10^{-7}$ \\
\hline & & Yusenko et al (43) & $\begin{array}{l}\text { Fetal kidney (2) } \\
\text { Kidney (3) }\end{array}$ & Renal wilms tumor (4) & -15.445 & -8.899 & $3.90 \times 10^{-5}$ \\
\hline & & Yusenko et al (43) & $\begin{array}{l}\text { Fetal kidney (2) } \\
\text { Kidney (3) }\end{array}$ & $\begin{array}{l}\text { Chromophobe renal } \\
\text { cell carcinoma (4) }\end{array}$ & -24.806 & -7.897 & $3.06 \times 10^{-4}$ \\
\hline & & Yusenko et al (43) & $\begin{array}{l}\text { Fetal kidney (2) } \\
\text { Kidney (3) }\end{array}$ & Renal oncocytoma (4) & -12.037 & -6.976 & $3.16 \times 10^{-4}$ \\
\hline & & Yusenko et al (43) & $\begin{array}{l}\text { Fetal kidney (2) } \\
\text { Kidney (3) }\end{array}$ & $\begin{array}{l}\text { Papillary renal cell } \\
\text { carcinoma (19) }\end{array}$ & -2.491 & -3.007 & 0.004 \\
\hline & & Yusenko et al (43) & $\begin{array}{l}\text { Fetal kidney (2) } \\
\text { Kidney (3) }\end{array}$ & $\begin{array}{l}\text { Clear cell renal } \\
\text { cell carcinoma }(26)\end{array}$ & -2.155 & -2.816 & 0.006 \\
\hline & & Jones et al (39) & Kidney (23) & $\begin{array}{l}\text { Renal pelvis urothelial } \\
\text { carcinoma ( } 8 \text { ) }\end{array}$ & -2.588 & -10.534 & $1.22 \times 10^{-11}$ \\
\hline & & Jones et al (39) & Kidney (23) & $\begin{array}{l}\text { Chromophobe renal cell } \\
\text { carcinoma (6) }\end{array}$ & -2.097 & -13.197 & $2.10 \times 10^{-9}$ \\
\hline & & Jones et al (39) & Kidney (23) & $\begin{array}{l}\text { Clear cell renal cell } \\
\text { carcinoma }(23)\end{array}$ & -2.48 & -6.97 & $8.02 \times 10^{-9}$ \\
\hline & & Gumz et al (40) & Kidney (10) & $\begin{array}{l}\text { Clear cell renal cell } \\
\text { carcinoma }(10)\end{array}$ & -3.346 & -7.187 & $6.29 \times 10^{-7}$ \\
\hline & & Beroukhim et al (41) & $\begin{array}{l}\text { Renal cortex (10) } \\
\text { Renal tissue (1) }\end{array}$ & $\begin{array}{l}\text { Non-hereditary clear } \\
\text { cell renal cell } \\
\text { carcinoma }(27)\end{array}$ & -5.56 & -6.922 & $5.03 \times 10^{-8}$ \\
\hline & & Beroukhim et al (41) & $\begin{array}{l}\text { Renal cortex (10) } \\
\text { Renal tissue (1) }\end{array}$ & $\begin{array}{l}\text { Hereditary clear cell } \\
\text { Renal cell carcinoma (32) }\end{array}$ & -4.687 & -7.061 & $1.26 \times 10^{-7}$ \\
\hline & & Lenburg et al (42) & Kidney (9) & $\begin{array}{l}\text { Clear cell renal cell } \\
\text { carcinoma (9) }\end{array}$ & -2.934 & -5.54 & $6.54 \times 10^{-5}$ \\
\hline & \multirow[t]{4}{*}{ TRPM4 } & Yusenko et al (43) & $\begin{array}{l}\text { Fetal kidney (2) } \\
\text { Kidney (3) }\end{array}$ & Renal oncocytoma (4) & 3.218 & 5.827 & $3.24 \times 10^{-4}$ \\
\hline & & Yusenko et al (43) & $\begin{array}{l}\text { Fetal kidney (2) } \\
\text { Kidney (3) }\end{array}$ & Renal oncocytoma (4) & -8.912 & -11.645 & $5.16 \times 10^{-6}$ \\
\hline & & Beroukhim et al (41) & $\begin{array}{l}\text { Renal cortex (10) } \\
\text { Renal tissue (1) }\end{array}$ & $\begin{array}{l}\text { Hereditary clear cell } \\
\text { Renal cell carcinoma (32) }\end{array}$ & -2.236 & -8.049 & $9.29 \times 10^{-8}$ \\
\hline & & Gumz et al (40) & Kidney (10) & $\begin{array}{l}\text { Clear cell renal cell } \\
\text { carcinoma }(10)\end{array}$ & -3.562 & -4.352 & $2.26 \times 10^{-4}$ \\
\hline & TRPM5 & Yusenko et al (43) & $\begin{array}{l}\text { Fetal kidney (2) } \\
\text { Kidney (3) }\end{array}$ & Renal wilms tumor (4) & 9.955 & 3.917 & 0.003 \\
\hline & TRPM7 & Yusenko et al (43) & $\begin{array}{l}\text { Fetal kidney (2) } \\
\text { Kidney (3) }\end{array}$ & Renal wilms tumor (4) & -2.16 & -6.705 & $6.05 \times 10^{-4}$ \\
\hline & TRPM8 & Yusenko et al (43) & $\begin{array}{l}\text { Fetal kidney (2) } \\
\text { Kidney (3) }\end{array}$ & $\begin{array}{l}\text { Papillary renal cell } \\
\text { carcinoma (19) }\end{array}$ & 22.217 & 4.332 & $5.07 \times 10^{-4}$ \\
\hline \multirow[t]{2}{*}{ Esophageal } & TRPM1 & Hao et al (44) & $\begin{array}{l}\text { Duodenum (13) } \\
\text { Esophagus (14) }\end{array}$ & $\begin{array}{l}\text { Esophageal } \\
\text { Adenocarcinoma (5) }\end{array}$ & -3.222 & -4.282 & $3.87 \times 10^{-4}$ \\
\hline & TRPM4 & Kimchi et al (45) & Esophagus (8) & Barrett's esophagus (8) & 4.661 & 3.301 & 0.003 \\
\hline
\end{tabular}


Table VII. Continued.

\begin{tabular}{|c|c|c|c|c|c|c|c|}
\hline $\begin{array}{l}\text { Cancer } \\
\text { type }\end{array}$ & Gene & Dataset & Normal (n) & Tumor type (n) & $\begin{array}{l}\text { Fold } \\
\text { change }\end{array}$ & t-test & P-value \\
\hline & & Kimchi et al (45) & Esophagus (8) & $\begin{array}{l}\text { Esophageal } \\
\text { adenocarcinoma (8) }\end{array}$ & 4.448 & 3.535 & 0.002 \\
\hline & & Kim et al (46) & Esophagus (28) & Barrett's esophagus (15) & 3.233 & 8.597 & $3.60 \times 10^{-8}$ \\
\hline & TRPM8 & Kimchi et al (45) & Esophagus (8) & $\begin{array}{l}\text { Esophageal } \\
\text { adenocarcinoma ( } 8)\end{array}$ & -3.315 & -3.413 & 0.003 \\
\hline \multirow[t]{10}{*}{$\begin{array}{l}\text { Brain and } \\
\text { CNS }\end{array}$} & TRPM2 & Liang et al (47) & $\begin{array}{l}\text { Brain (2) } \\
\text { Cerebellum (1) }\end{array}$ & Oligoastrocytoma (3) & -2.694 & -4.518 & 0.007 \\
\hline & & Bredel et al (48) & Brain (4) & $\begin{array}{l}\text { Anaplastic } \\
\text { oligodendroglioma (3) }\end{array}$ & -4.071 & -5.62 & 0.005 \\
\hline & TRPM3 & Lee et al (49) & $\begin{array}{l}\text { Neural stem } \\
\text { cell }(3)\end{array}$ & Glioblastoma (22) & 4.661 & 3.301 & $5.67 \times 10^{-5}$ \\
\hline & & Sun et al (50) & Brain (23) & Oligodendroglioma (50) & -2.286 & -8.417 & $3.95 \times 10^{-12}$ \\
\hline & & Sun et al (50) & Brain (23) & Glioblastoma (81) & -2.447 & -10.147 & $2.32 \times 10^{-17}$ \\
\hline & & TCGA & Brain (10) & Brain glioblastoma (542) & -16.791 & -16.791 & $1.92 \times 10^{-9}$ \\
\hline & & Murat et al (51) & Brain (4) & Glioblastoma (80) & -2.46 & -5.563 & 0.001 \\
\hline & TRPM6 & Sun et al (50) & Brain (23) & Diffuse astrocytoma (7) & -2.5 & -3.865 & 0.001 \\
\hline & TRPM8 & Murat et al (51) & Brain (4) & Glioblastoma (80) & 2.49 & 8.432 & $4.39 \times 10^{-11}$ \\
\hline & & Lee et al (49) & $\begin{array}{l}\text { Neural stem } \\
\text { cell }(3)\end{array}$ & Glioblastoma (22) & 5.257 & 6.712 & $4.98 \times 10^{-6}$ \\
\hline $\begin{array}{l}\text { Head and } \\
\text { neck }\end{array}$ & TRPM1 & Ginos et al (52) & $\begin{array}{l}\text { Buccal } \\
\text { Mucosa (13) }\end{array}$ & $\begin{array}{l}\text { Head and neck squamous } \\
\text { cell carcinoma ( } 41)\end{array}$ & -5.324 & -8.031 & $1.52 \times 10^{-10}$ \\
\hline
\end{tabular}

TRPMs, Transient Receptor Potential Melastatin; TCGA, The Cancer Genome Atlas; CNS, central nervous system.

prognostic biomarker for lung adenocarcinoma; consistent with the results of Huang et al (67), which demonstrate that the knockdown of TRPM2-antisense also significantly inhibited cell proliferation.

Colorectal cancer is the third most common diagnosed type of cancer in humans which poses a significant public health issue worldwide, with $>1.8$ million cases diagnosed each year $(1,68)$. As a result of the numerous studies investigating TRPM channels and colorectal cancer, tumor treatment options are becoming more diverse and accurate for colorectal cancer. The present study revealed that TRPM1, TRPM2 and TRPM6 may serve as diagnostic markers for the prognosis of colorectal cancer development and are useful targets for pharmaceutical interventions. These data provide evidence to support the hypothesis that TRPM1, TRPM2 and TRPM6 serve a crucial role in tumor growth and metastasis formation (8).

The results of the present study may contribute to a more complete understanding of the expression levels and prognostic values of TRPM family members in certain solid tumors, including gastric cancer, which causes nearly 1 million mortalities worldwide each year $(1,69,70)$. Certain cell channels, including TRP, are more active or are upregulated in gastric cancer cells (70). The present study suggested that the abnormal regulation of TRPM1, TRPM2 and TRPM3 may be vital in the development of intestinal type gastric cancer. They may participate in different stages of tumorigenesis. Not all TRPM channels have been investigated thoroughly and the current literature base remains inadequate. The results from the present study regarding TRPM2 expression are in concordance with the data from the study by Almasi et al (71), which suggested that TRPM2 knockdown inhibits cell proliferation, and promotes apoptosis in gastric cancer cells. However, research is currently focused on TRPM7, and there are few studies on TRPM1 and TRPM3. Therefore, future studies investigating these specific proteins are required.

The present study aimed to assess the importance of TRPMs in liver cancer, the fourth most common cause of mortality associated with cancer (1). The most significant finding from the present study was that the OS time of patients with liver cancer exhibiting increased TRPM8 expression levels was significantly shorter compared with those patients with decreased TRPM8 expression. This suggested that TRPM8 may be a novel marker for liver cancer survival and prognostic accuracy. However, these results must be interpreted with caution, as further work is required in order to establish the viability of this new marker.

Prostate cancer is a common form of cancer in adult males which is responsible for one-fourth of all incident cancer cases in western countries, with its incidence continuing to increase $(66,72)$. The present study suggested that TRPM8 served a key role in mediating the biological behavior of prostate tumors, consistent with the results of numerous independent studies demonstrating that TRPM8 was important for the survival, migration and invasion of prostate cancer cells $(73,74)$ 
Deeds et al (75) demonstrated that TRPM1 was expressed at high levels in poorly metastatic variants of the melanoma cell line. The Oncomine database and the Kaplan-Meier plotter survival analyses performed in the present study also demonstrated that TRPM1 was considered to be a tumor activator of melanoma. The data implied that low TRPM1 expression levels were associated with decreased OS rates in comparison with high TRPM1 levels. When examining TRPM4, the results of the present study also suggested that it may serve as a factor in regulating melanoma proliferation, apoptosis and necrosis.

In the present study, it was also revealed that the downregulation of TRPM4 expression was associated with improved OS in patients with glioma. In addition, the potential association between TRPM8 and esophageal cancer OS was measured, and the results implied that TRPM8 may be a prognostic marker and potential therapeutic target for esophageal cancer. However, this family appears to not be associated with OS in kidney cancer and head and neck cancer.

In summary, the results of the present study indicated that certain members of the TRPM protein family exhibit significant differences in mRNA expression levels between cancer and control tissues. A number of these proteins may be useful biomarkers for cancer prognosis, and may represent novel anticancer targets.

\section{Acknowledgements}

Not applicable.

\section{Funding}

The present study was supported by Projects from the Scientific Research Fund of Zhejiang Provincial Education Department (grant no. Y201941836), the Natural Science Foundation of Zhejiang Province (grant no. LGF19H090007) and the Traditional Chinese Medicine Science and Technology Plan of Zhejiang Province (grant no. 2019ZB030).

\section{Availability of data and materials}

The datasets used and/or analyzed during the present study are available from the corresponding author on reasonable request.

\section{Authors' contributions}

FHQ and XLM were responsible for the Oncomine and Kaplan-Meier plotter analysis and writing the original draft. LDL was involved in the PrognoScan analysis and interpretation of the data, and revising the manuscript critically for important intellectual content. MHH was involved in revising the manuscript and participated in the interpretation of data. HT made contributions to the acquistion of data. XHJ was involved in the GEPIA analysis and interpretation of the data. JPZ was responsible for the conception, design of the study and revising the manuscript critically for important intellectual content. All authors reviewed and approved the final manuscript.

\section{Ethics approval and consent to participate}

Not applicable.

\section{Patient consent for publication}

Not applicable.

\section{Competing interests}

The authors declare that they have no competing interests.

\section{References}

1. Bray F, Ferlay J, Soerjomataram I, Siegel RL, Torre LA and Jemal A: Global cancer statistics 2018: GLOBOCAN estimates of incidence and mortality worldwide for 36 cancers in 185 countries. CA Cancer J Clin 68: 394-424, 2018.

2. Fidler MM, Soerjomataram I and Bray F: A global view on cancer incidence and national levels of the human development index. Int J Cancer 139: 2436-2446, 2016.

3. Montell C and Rubin GM: Molecular characterization of the Drosophila trp locus: A putative integral membrane protein required for phototransduction. Neuron 2: 1313-1323, 1989.

4. Schmitz C and Perraud AL: The TRPM cation channels in the immune context. Curr Pharm Design 11: 2765-2778, 2005.

5. Zeng X, Sikka SC, Huang L, Sun C, Xu C, Jia D, Abdel-Mageed AB, Pottle JE, Taylor JT and Li M: Novel role for the transient receptor potential channel TRPM2 in prostate cancer cell proliferation. Prostate Cancer Prostatic Dis 13: 195-201, 2010.

6. Armisen R, Marcelain K, Simon F, Tapia JC, Toro J, Quest AF and Stutzin A: TRPM4 enhances cell proliferation through up-regulation of the $\beta$-catenin signaling pathway. J Cell Physiol 226: 103-109, 2011.

7. Meng X, Cai C, Wu J, Cai S, Ye C, Chen H, Yang Z, Zeng H, Shen Q and Zou F: TRPM7 mediates breast cancer cell migration and invasion through the MAPK pathway. Cancer Lett 333: 96-102, 2013

8. Hantute-Ghesquier A, Haustrate A, Prevarskaya N and Lehen'kyi V: TRPM family channels in cancer. Pharmaceuticals (Basel) 11: 2, 2018.

9. Wong KK, Banham AH, Yaacob NS and Nur Husna SM: The oncogenic roles of TRPM ion channels in cancer. J Cell Physiol, 2019.

10. Nagy Á, Lánczky A, Menyhárt O and Győrffy B: Validation of miRNA prognostic power in hepatocellular carcinoma using expression data of independent datasets. Sci Rep 8: 9227, 2018.

11. Li Q, Birkbak NJ, Gyorffy B, Szallasi Z and Eklund AC: Jetset: Selecting an optimal microarray probe set to represent a gene. BMC Bioinformatics 12: 474, 2011.

12. Mizuno H, Kitada K, Nakai K and Sarai A: PrognoScan: A new database for meta-analysis of the prognostic value of genes. BMC Med Genomics 2: 18, 2009.

13. Tang Z, Li C, Kang B, Gao G, Li C and Zhang Z: GEPIA: A web server for cancer and normal gene expression profiling and interactive analyses. Nucleic Acids Res 45: W98-W102, 2017.

14. Siegel R, Naishadham D and Jemal A: Cancer statistics, 2012. CA Cancer J Clin 62: 10-29, 2012.

15. Gyorffy B, Lanczky A, Eklund AC, Denkert C, Budczies J, Li Q and Szallasi Z: An online survival analysis tool to rapidly assess the effect of 22,277 genes on breast cancer prognosis using microarray data of 1,809 patients. Breast Cancer Res Treat 123: 725-731, 2010.

16. Bhattacharjee A, Richards WG, Staunton J, Li C, Monti S, Vasa P, Ladd C, Beheshti J, Bueno R, Gillette M, et al: Classification of human lung carcinomas by mRNA expression profiling reveals distinct adenocarcinoma subclasses. Proc Natl Acad Sci USA 98: 13790-13795, 2001.

17. Garber ME, Troyanskaya OG, Schluens K, Petersen S, Thaesler Z, Pacyna-Gengelbach M, van de Rijn M, Rosen GD, Perou CM, Whyte RI, et al: Diversity of gene expression in adenocarcinoma of the lung. Proc Natl Acad Sci USA 98: 13784-13789, 2001.

18. Okayama H, Kohno T, Ishii Y, Shimada Y, Shiraishi K, Iwakawa R, Furuta K, Tsuta K, Shibata T, Yamamoto S, et al: Identification of genes upregulated in ALK-positive and EGFR/KRAS/ALK-negative lung adenocarcinomas. Cancer Res 72: 100-111, 2012.

19. Gyorffy B, Surowiak P, Budczies J and Lanczky A: Online survival analysis software to assess the prognostic value of biomarkers using transcriptomic data in non-small-cell lung cancer. PLoS One 8: e82241, 2013. 
20. Skrzypczak M, Goryca K, Rubel T, Paziewska A, Mikula M, Jarosz D, Pachlewski J, Oledzki J and Ostrowski J: Modeling oncogenic signaling in colon tumors by multidirectional analyses of microarray data directed for maximization of analytical reliability. PLoS One 5: pii: e13091, 2010.

21. Hong Y, Downey T, Eu KW, Koh PK and Cheah PY: A 'metastasis-prone' signature for early-stage mismatch-repair proficient sporadic colorectal cancer patients and its implications for possible therapeutics. Clin Exp Metastasis 27: 83-90, 2010.

22. Sabates-Bellver J, Van der Flier LG, de Palo M, Cattaneo E, Maake C, Rehrauer H, Laczko E, Kurowski MA, Bujnicki JM, Menigatti M, et al: Transcriptome profile of human colorectal adenomas. Mol Cancer Res 5: 1263-1275, 2007.

23. Skrzypczak M, Goryca K, Rubel T, Paziewska A, Mikula M, Jarosz D, Pachlewski J, Oledzki J and Ostrowski J: Modeling oncogenic signaling in colon tumors by multidirectional analyses of microarray data directed for maximization of analytical reliability. PLoS One 5: pii: e13091, 2010.

24. Gaedcke J, Grade M, Jung K, Camps J, Jo P, Emons G, Gehoff A Sax U, Schirmer M, Becker H, et al: Mutated KRAS results in overexpression of DUSP4, a MAP-kinase phosphatase and SMYD3, a histone methyltransferase, in rectal carcinomas. Genes Chromosomes Cancer 49: 1024-1034, 2010.

25. Kaiser S, Park YK, Franklin JL, Halberg RB, Yu M, Jessen WJ, Freudenberg J, Chen X, Haigis K, Jegga AG, et al: Transcriptional recapitulation and subversion of embryonic colon development by mouse colon tumor models and human colon cancer. Genome Biol 8: R131, 2007.

26. D'Errico M, de Rinaldis E, Blasi MF, Viti V, Falchetti M, Calcagnile A, Sera F, Saieva C, Ottini L, Palli D, et al: Genome-wide expression profile of sporadic gastric cancers with microsatellite instability. Eur J Cancer 45: 461-469, 2009.

27. Wang Q, Wen YG, Li DP, Xia J, Zhou CZ, Yan DW, Tang HM and Peng ZH: Upregulated INHBA expression is associated with poor survival in gastric cancer. Med Oncol 29: 77-83, 2012.

28. Tomlins SA, Mehra R, Rhodes DR, Cao X, Wang L, Dhanasekaran SM, Kalyana-Sundaram S, Wei JT, Rubin MA, Pienta KJ, et al: Integrative molecular concept modeling of prostate cancer progression. Nat Genet 39: 41-51, 2007.

29. VVarambally S, Yu J, Laxman B, Rhodes DR, Mehra R, Tomlins SA, Shah RB, Chandran U, Monzon FA, Becich MJ et al: Integrative genomic and proteomic analysis of prostate cancer reveals signatures of metastatic progression. Cancer Cell 8 : 393-406, 2005

30. Liu P, Ramachandran S, Ali Seyed M, Scharer CD, Laycock N, Dalton WB, Williams H, Karanam S, Datta MW, Jaye DL, et al: Sex-determining region $\mathrm{Y}$ box 4 is a transforming oncogene in human prostate cancer cells. Cancer Res 66: 4011-4019, 2006.

31. Vanaja DK, Cheville JC, Iturria SJ and Young CYF: Transcriptional silencing of zinc finger protein 185 identified by expression profiling is associated with prostate cancer progression. Cancer Res 63: 3877-3882, 2003.

32. Grasso CS, Wu YM, Robinson DR, Cao X, Dhanasekaran SM, Khan AP, Quist MJ, Jing X, Lonigro RJ, Brenner JC, Asangani IA, et al: The mutational landscape of lethal castration-resistant prostate cancer. Nature 487: 239-243, 2012.

33. Arredouani MS, Lu B, Bhasin M, Eljanne M, Yue W, Mosquera JM, Bubley GJ, Li V, Rubin MA, Libermann TA, et al: Identification of the transcription factor single-minded homologue 2 as a potential biomarker and immunotherapy target in prostate cancer. Clin Cancer Res 15: 5794-5802, 2009.

34. Wallace TA, Prueitt RL, Yi M, Howe TM, Gillespie JW, Yfantis HG, Stephens RM, Caporaso NE, Loffredo CA and Ambs S: Tumor immunobiological differences in prostate cancer between African-American and European-American men. Cancer Res 68: 927-936, 2008

35. Talantov D, Mazumder A, Yu JX, Briggs T, Jiang Y, Backus J, Atkins D and Wang Y: Novel genes associated with malignant melanoma but not benign melanocytic lesions. Clin Cancer Res 11: 7234-7242, 2005.

36. Haqq C, Nosrati M, Sudilovsky D, Crothers J, Khodabakhsh D, Pulliam BL,Federman S, Miller JR III, Allen RE, Singer MI, et al: The gene expression signatures of melanoma progression. Proc Natl Acad Sci USA 102: 6092-6097, 2005.

37. Riker AI, Enkemann SA, Fodstad O, Liu S, Ren S, Morris C, Xi Y, Howell P, Metge B, Samant RS, et al: The gene expression profiles of primary and metastatic melanoma yields a transition point of tumor progression and metastasis. BMC Med Genomics 1: 13, 2008.
38. Cutcliffe C, Kersey D, Huang CC, Zeng Y, Walterhouse D and Perlman EJ: Clear cell sarcoma of the kidney: up-regulation of neural markers with activation of the sonic hedgehog and Akt pathways. Clin Cancer Res 11: 7986-7994, 2005

39. Jones J1, Otu H, Spentzos D, Kolia S, Inan M, Beecken WD, Fellbaum C, Gu X, Joseph M, Pantuck AJ, et al: Gene signatures of progression and metastasis in renal cell cancer. Clin Cancer Res 11: 5730-5739, 2005.

40. Gumz ML1, Zou H, Kreinest PA, Childs AC, Belmonte LS, LeGrand SN, Wu KJ, Luxon BA, Sinha M, Parker AS, et al: Secreted frizzled-related protein 1 loss contributes to tumor phenotype of clear cell renal cell carcinoma. Clin Cancer Res 13: 4740-4749, 2007.

41. Beroukhim R1, Brunet JP, Di Napoli A, Mertz KD, Seeley A, Pires MM, Linhart D, Worrell RA, Moch H, Rubin MA, et al: Patterns of gene expression and copy-number alterations in von-hippel lindau disease-associated and sporadic clear cell carcinoma of the kidney. Cancer Res 69: 4674-4681, 2009.

42. Lenburg ME, Liou LS, Gerry NP, Frampton GM, Cohen HT and Christman MF: Previously unidentified changes in renal cell carcinoma gene expression identified by parametric analysis of microarray data. BMC Cancer 3: 31, 2003.

43. Yusenko MV, Kuiper RP, Boethe T, Ljungberg B, van Kessel AG and Kovacs G: High-resolution DNA copy number and gene expression analyses distinguish chromophobe renal cell carcinomas and renal oncocytomas. BMC Cancer 9: 152, 2009.

44. Hao Y, Triadafilopoulos G, Sahbaie P, Young HS, Omary MB and Lowe AW: Gene expression profiling reveals stromal genes expressed in common between Barrett's esophagus and adenocarcinoma. Gastroenterology 131: 925-933, 2006.

45. Kimchi ET, Posner MC, Park JO, Darga TE, Kocherginsky M, Karrison T, Hart J, Smith KD, Mezhir JJ, Weichselbaum RR et al.: Progression of Barrett's metaplasia to adenocarcinoma is associated with the suppression of the transcriptional programs of epidermal differentiation. Cancer Res 65: 3146-3154, 2005.

46. Kim SM, Park YY, Park ES, Cho JY, Izzo JG, Zhang D, Kim SB, Lee JH, Bhutani MS, Swisher SG, Wu X, Coombes KR, et al.: Prognostic biomarkers for esophageal adenocarcinoma identified by analysis of tumor transcriptome. PLoS One 5: e15074, 2010.

47. Liang Y, Diehn M, Watson N, et al.: Gene expression profiling reveals molecularly and clinically distinct subtypes of glioblastoma multiforme. Proc Natl Acad Sci U S A 102: 5814-5819, 2005.

48. Bredel M1, Bredel C, Juric D, Harsh GR, Vogel H, Recht LD and Sikic BI: Functional network analysis reveals extended gliomagenesis pathway maps and three novel MYC-interacting genes in human gliomas. Cancer Res 65: 8679-8689, 2005.

49. Lee J, Kotliarova S, Kotliarov Y, Li A, Su Q, Donin NM, Pastorino S, Purow BW, Christopher N, Zhang W, et al: Tumor stem cells derived from glioblastomas cultured in bFGF and EGF more closely mirror the phenotype and genotype of primary tumors than do serum-cultured cell lines. Cancer Cell 9: 391-403, 2006.

50. Sun L1, Hui AM, Su Q, Vortmeyer A, Kotliarov Y, Pastorino S, Passaniti A, Menon J, Walling J, Bailey R, et al.: Neuronal and glioma-derived stem cell factor induces angiogenesis within the brain. Cancer Cell 9: 287-300, 2006.

51. Murat A, Migliavacca E, Gorlia T, Lambiv WL, Shay T, Hamou MF, de Tribolet N, Regli L, Wick W, Kouwenhoven MC, et al: Stem cell-related 'self-renewal' signature and high epidermal growth factor receptor expression associated with resistance to concomitant chemoradiotherapy in glioblastoma. J Clin Oncol 26: 3015-3024, 2008.

52. Ginos MA, Page GP, Michalowicz BS, Patel KJ, Volker SE, Pambuccian SE, Ondrey FG, Adams GL and Gaffney PM: Identification of a gene expression signature associated with recurrent disease in squamous cell carcinoma of the head and neck. Cancer Res 64: 55-63, 2004.

53. Maule M and Merletti F: Cancer transition and priorities for cancer control. Lancet Oncol 13: 745-746, 2012.

54. Bray F, Soerjomataram I, Mery L and Ferlay J: Improving the quality and coverage of cancer registries globally. Lancet 386 : 1035-1036, 2015

55. Chen J, Luan Y, Yu R, Zhang Z, Zhang J and Wang W: Transient receptor potential (TRP) channels, promising potential diagnostic and therapeutic tools for cancer. Biosci Trends 8: 1-10, 2014.

56. Clapham DE: TRP channels as cellular sensors. Nature 426: 517-524, 2003.

57. Pedersen SF, Owsianik G and Nilius B: TRP channels: An overview. Cell Calcium 38: 233-252, 2005. 
58. Gkika D and Prevarskaya N: Molecular mechanisms of TRP regulation in tumor growth and metastasis. Biochim Biophys Acta 1793: 953-958, 2009.

59. Winters S, Martin C, Murphy D and Shokar NK: Breast cancer epidemiology, prevention and screening. Prog Mol Biol Transl 151: 1-32, 2017.

60. Dai X, Xiang L, Li T and Bai Z: Cancer hallmarks, biomarkers and breast cancer molecular subtypes. J Cancer 7: 1281-1294, 2016.

61. Dai X, Li T, Bai Z, Yang Y, Liu X, Zhan J and Shi B: Breast cancer intrinsic subtype classification, clinical use and future trends. Am J Cancer Res 5: 2929-2943, 2015.

62. Spitale A, Mazzola P, Soldini D, Mazzucchelli L and Bordoni A: Breast cancer classification according to immunohistochemica markers: Clinicopathologic features and short-term survival analysis in a population-based study from the South of Switzerland. Ann Oncol 20: 628-635, 2009.

63. Sumoza-Toledo A,Espinoza-Gabriel MI and Montiel-Condado D: Evaluation of the TRPM2 channel as a biomarker in breast cancer using public databases analysis. Bol Med Hosp Infant Mex 73 397-404, 2016.

64. Stephens PJ, Tarpey PS, Davies H, Van Loo P, Greenman C, Wedge DC, Nik-Zainal S, Martin S, Varela I, Bignell GR, et al: The landscape of cancer genes and mutational processes in breast cancer. Nature 486: 400-404, 2012.

65. Chen W, Zheng R, Baade PD, Zhang S, Zeng H, Bray F, Jemal A, Yu XQ and He J: Cancer statistics in China, 2015. CA Cancer J Clin 66: 115-132, 2016.

66. Siegel RL, Miller KD and Jemal A: Cancer statistics, 2017. CA Cancer J Clin 67: 7-30, 2017.

67. Huang C, Qin Y, Liu H, Liang N, Chen Y, Ma D, Han Z, Xu X, Zhou X, He J and Li S: Downregulation of a novel long noncoding RNA TRPM2-AS promotes apoptosis in non-small cell lung cancer. Tumour Biol 39: 1010428317691191, 2017.
68. Arnold M, Sierra MS, Laversanne M, Soerjomataram I, Jemal A and Bray F: Global patterns and trends in colorectal cancer incidence and mortality. Gut 66: 683-691, 2017.

69. Bray F, Ren JS, Masuyer E and Ferlay J: Global estimates of cancer prevalence for 27 sites in the adult population in 2008. Int J Cancer 132: 1133-1145, 2013.

70. Kim BJ, Kim SY, Lee S, Jeon JH, Matsui H, Kwon YK, Kim SJ and So I: The role of transient receptor potential channel blockers in human gastric cancer cell viability. Can J Physiol Pharmacol 90: 175-186, 2012.

71. Almasi S, Kennedy BE, El-Aghil M, Sterea AM, Gujar S, Partida-Sánchez S and El Hiani Y: TRPM2 channel-mediated regulation of autophagy maintains mitochondrial function and promotes gastric cancer cell survival via the JNK-signaling pathway. J Biol Chem 293: 3637-3650, 2018.

72. Jemal A, Siegel R, Ward E, Hao Y, Xu J and Thun MJ: Cancer statistics, 2009. CA Cancer J Clin 59: 225-249, 2009.

73. Bidaux G, Borowiec AS, Dubois C, Delcourt P, Schulz C, Vanden Abeele F, Lepage G, Desruelles E, Bokhobza A, Dewailly E, et al: Targeting of short TRPM8 isoforms induces 4TM-TRPM8-dependent apoptosis in prostate cancer cells. Oncotarget 7: 29063-29080, 2016.

74. Peng M, Wang Z, Yang Z, Tao L, Liu Q, Yi LU and Wang X: Overexpression of short TRPM8 variant a promotes cell migration and invasion and decreases starvation-induced apoptosis in prostate cancer LNCaP cells. Oncol Lett 10: 1378-1384, 2015.

75. Deeds J, Cronin F and Duncan LM: Patterns of melastatin mRNA expression in melanocytic tumors. Hum Pathol 31: 1346-1356, 2000.

This work is licensed under a Creative Commons Attribution-NonCommercial-NoDerivatives 4.0 International (CC BY-NC-ND 4.0) License. 